\title{
Demystifying the Prudential Carve-out: A proposal ${ }^{1}$
}

\author{
Samuel Trujillo ${ }^{2}$
}

\section{ABSTRACT}

This article explores how the broadest spirited exception in the framework of the World Trade Organization, commonly referred to as the prudential carve-out, could be applied without adding to or diminishing the rights and obligations of WTO Members. It argues that through the customary rules of interpretation of international law, the only standard applicable to the prudential carve out is that of a reasonable means to ends connection. However, this broad standard of review can be enriched by expert knowledge on financial and prudential regulation, given that the form of dispute settlement established in the Annex to Financial Services of the GATS provides a window for dissecting the concept of "prudential". The AFS requires that an "expert panel" decide on controversies regarding financial and prudential issues, instead of the ordinary "highly qualified" WTO panel. The article draws on principles developed by the disciplines of

1 Una versión anterior de este trabajo se presentó como requisito para obtener el título de Abogado. Esta versión está actualizada y adaptada al formato de la revista. Since the writing of this article, the prudential carve-out has been addressed by the Panel in Argentina - Measures Relating to Trade in Goods and Services (September 30, 2015), see pp 7.811-7.949.

Para citar el artículo: Trujillo, S. (2015). Demystifying the Prudential Carve-out: a proposal. Revista Contexto, (43), pp. 157-208. DOI: http://dx.doi.org/10.18601/01236458.n43.05

2 Abogado de la Universidad Externado de Colombia, eximido de presentar exámenes preparatorios por el alto rendimiento académico. Representó a su universidad en las competencias internacionales Phillip C. Jessup Moot Court, European Law Students Association Moot Court y Foreign Direct Investment International Arbitration Moot. Asociado en Brigard \& Urrutia Abogados, donde apoya operaciones de financiación nacionales e internacionales como miembro del Equipo de Derecho Bancario y Servicios Financieros. Correo electrónico: samuel.trujillo@est.uexternado.edu.co Attorney from Universidad Externado School of Law, exempted from presenting preparatory exams due to academic performance. He represented his University in the international competitions Phillip C. Jessup Moot Court, European Law Students Association Moot Court, and Foreign Direct Investment International Arbitration Moot. Associate at Brigard \& Urrutia Abogados where ass part of the Banking and Financial Services Team he assists in national and international finance operations. 
micro- and macroprudential regulation to exemplify how expert knowledge can guide an otherwise vague standard of review.

Keywords: World Trade Organization, General Agreement on Trade in Services, prudential Carve-out, expert panel, micro-prudential regulation, macro-prudential regulation.

\section{DESMITIFICANDO LA EXCEPCIÓN CAUTELAR: UNA PROPUESTA}

\section{RESUMEN}

Este artículo explora cómo la excepción con el espíritu más amplio en el marco de la Organización Mundial de Comercio, conocida como la excepción cautelar, puede ser aplicada sin disminuir, o agregarle a, los derechos y obligaciones de los miembros. Argumenta que, a través de las reglas consuetudinarias de interpretación del derecho internacional, el único estándar aplicable a la excepción cautelar es el de una conexión razonable entre medios y fines. Sin embargo, este amplio criterio de revisión puede ser enriquecido por conocimiento experto en regulación financiera y prudencial, ya que el Anexo a Servicios Financieros del AGCS establece que debe ser un panel experto el que decida controversias sobre cuestiones financieras y prudenciales, en vez del panel "altamente cualificado" ordinario. El artículo hace referencia a principios desarrollados por las disciplinas de regulación micro y macroprudencial para ejemplificar cómo dicho conocimiento experto puede guiar un criterio de revisión, de otra forma vago.

Palabras clave: Organización Mundial del Comercio, Acuerdo General sobre Comercio de Servicios, excepción cautelar, panel experto, regulación micro-prudencial, regulación macroprudencial.

\section{INTRODUCTION: THE PRUDENTIAL CARVE-OUT'S RELEVANCE AND ITS PROBLEMATIC}

The Annex on Financial Services (AFS) to the World Trade Organization's (WTO) General Agreement on Trade in Services (GATS) establishes in an exception that allows Member States, notwithstanding any other provisions of the Agreement to adopt measures for prudential reasons. An analysis of this provision, commonly referred to as the prudential carve-out, is relevant as it has yet to be invoked by any WTO Member, and consequently lacks a clear scope of application ${ }^{3}$. Furthermore, despite not having been invoked before

3 Mamiko Yokio-AraI, "GATs' Prudential Carve Out in Financial Services and Its Relation with Prudential Regulation" (2008) 57 Int'l \& Comp. L.Q. 613 at 639 [Yokio-Arai]; SYDNEY J. KEY, "Trade liberalization and prudential regulation: the international framework for financial services" (1999) 75 R.I.I.A. 61 at 67 $68[\mathrm{Key}]$ Mary MCAllister Shepro, "Preserving National Regulatory Autonomy in Financial Services: The GATS' Prudential Carve-Out" (2013) Notre Dame University (QL) [McAllister]; Panagiotis Delimatsis 
an international tribunal, the prudential carve-out has proliferated in many other instruments of international law ${ }^{4}$ as it can be found in many Free Trade Agreements (FTAs).

Consequently this provision and the mist surrounding it, not only envelop the multilateral trading system as the prudential carve-out also constitutes applicable law in a significant quantity of bilateral and regional trade relations. As a result of the most recent global financial crisis and the subsequent concern regarding banking regulation, the legal vacuum regarding the exception's correct interpretation and application is further highlighted.

The problem centers on determining what can be considered "prudential", and the limits to the use of the prudential carve-out. Following DSU Article 3.2, this analysis cannot add to, or diminish the rights and obligations of WTO Members, as these may only be clarified through the application of customary rules of interpretation of public international law. Such interpretative processes is difficult since most WTO Members did not, and still do not, wish to clearly determine the meaning of "prudential", both in the WTO framework and in their regional and bilateral trade relations. Instead, they find comfort in the mist that surrounds the provision.

As the comfort that most WTO Members currently enjoy in the prudential carveout's ambiguity could one day be challenged, a WTO Panel would have the need, and obligation, to clarify the provision's content. The purpose of this work is to show how this could be achieved, removing the mist that surrounds the provision in a manner consistent with WTO interpretation that respects and follows the will of its Members.

The starting point in the analysis, is to understand the WTO concept of a "measure", which unlike the concept of prudential, has been addressed by the Appellate Body (Section II). Such understanding will demonstrate the existence of a vast panorama of situations in which the prudential carve-out could be found to be applicable. Subsequently, the analysis will compare the original AFS prudential carve-out with those introduced into the FTA's of some of the most representative WTO Members (Section III). Such comparison will provide perspective as to the evolution of the provision, showing that there are two main approaches preferred by certain WTO Members. One of these approaches strives to severely limit the provision.

Afterwards, Section IV will show to what extent the prudential carve-out's ambiguity can be limited through a strict analysis that follows the customary rules for the interpretation of treaties. First through an interpretation the follows the general rule, and then recurring to the supplementary means, seeking to confirm and further clarify the will of the WTO Members. This Section will show that although prudential measures must have a reasonable means to ends connection with the legitimate objectives they peruse, a narrower standard cannot be applied. As Section IV will demonstrate certain conformity

\& Pierre Suavé, "Financial services trade after the crisis: Policy and legal conjectures" (2010) 13(3) J. Int'1 Econ. L. 837 at 849 [Delimatsis \& Suavé]. 
by WTO Members regarding the provision's ambiguity, Section V will analyze whether such state of mind still exists today.

Section V will demonstrate that WTO Members are still reluctant in determining a more tangible meaning regarding the provision. Consequently, the work presented will contend that this traditional interpretation, which would be undertaken by an ordinary WTO Panel, would fall short. It does provide some clarity as to the provision's scope of application, but fails to fully demystify the provision. However, Section VI seeks to aide this situation, and argues that despite failing to provide a tangible content to the concept of "prudential", the traditional interpretation, expected of any ordinary WTO Panel, does provide the key for demystifying the provision.

This crucial element is the form of dispute settlement specifically established by WTO Members in the AFS, which provides a window for consolidating the term "prudential". By requiring an expert Panel, as opposed to an ordinary Panel, dispute settlement in the AFS calls for the application of expert knowledge on prudential and financial issues. In essence, the "reasonable means to ends connection" that prudential measures must have, can be evaluated through more specified and specialized elements that the expert knowledge on prudential and financial matters provides.

Section VII provides an example of the expert knowledge that a Panel could apply when determining whether a measure truly is prudential, making use of two disciplines developed in international finance law and regulation. These are macro- and microprudential policy, which have a concrete link with the legitimate objectives that the carve-out intends to protect. Lastly, Section VIII synthetizes the previously reached conclusions, and contends that through the proposed analysis a WTO Panel can adequately clarify and apply the prudential carve-out on a case by case basis, in a manner that is consistent with proper WTO interpretation.

\section{THE CONCEPT OF "MEASURE" UNDER THE GATS}

Before facing the challenge of determining what a measure taken for a prudential reason consists of, we can identify the general concept of "measures" within the WTO. This serves to illustrate what exactly could be challenged, and would therefore be susceptible to finding refuge in the prudential carve-out. Unlike the concept of "prudential", the notion of "measures" has found development in the WTO, ergo before interpreting the term "prudential", we can form an idea as to what these measures can involve.

GATS Article 1 when establishing the scope of the Agreement addresses "measures by Members affecting trade in services ${ }^{\prime \prime}$. Additionally, GATS Article XXVIII(a) loosely defines the term as "any measure by a Member, whether in the form of a law, regulation, rule, procedure, decision, administrative action, or any other form ${ }^{\prime \prime}$. This is a broad definition as 
recognized by the Panel in China-EPS ${ }^{7}$ since even the administrative application of general instruments like laws, constitutes a measure under the GATS ${ }^{8}$. Moreover, for purposes of dispute settlement, a measure can be "[i] n principle, any act or omission attributable to a WTO Member ${ }^{\prime \prime}$. usually one of its organs ${ }^{10}$, including the executive branch ${ }^{11}$.

This is of particular importance when dealing with prudential regulation since the legal framework can grant administrative authorities a degree of discretion when applying prudential measures, and consequently noncompliance with GATS commitments could result from the regulation's application ${ }^{12}$.

The scope of the GATS requires that the measure must affect trade in services, a concept that has also been developed by the Appellate Body. Like the term "measure", the term "affect" has received a broad interpretation: "[ $t]$ he ordinary meaning of the word 'affecting' implies a measure that has 'an effect on', which indicates a broad scope of application"13. Despite its broad scope, it is not an analysis that can be overlooked, and requires determining whether the trade in services effectively exists as one of the four forms of supply, and whether the measure at hand has an effect on the supply of the services, or on the service suppliers ${ }^{14}$.

Given the broad concept of measures that affects trade in services, GATS provisions are applicable to a great variety of acts or omissions attributable to a State, depending on the level of commitments undertaken. ${ }^{15}$ In the context of financial services, the prudential carve-out could allow the inconsistency with any GATS commitment by such a wide array of measures, provided they are taken from prudential reasons.

7 China-Certain Measures Affecting Electronic Payment Services (Complaint by United States) (2009) WTO Doc WT/ DS413/R (Panel Report) para.7.219.

8 European Communities-Customs Classification of Certain Computer Equipment (Complaint by United States) (1998) WTO Doc WT/DS62/AB/R (Appellate Body Report) para 65, [EC - Computer Equipment]; Miguel CASTRORiberos, "Colombia's Policy Space for Prudential Regulation: an Analysis from its International Trade Commitments" (2013) 23 Rev col der intern. 119 at 124 [Castro-Riberos].

9 United States - Sunset Review of Anti-Dumping Duties on Corrosion-Resistant Carbon Steel Flat Products from Japan (Complaint by Japan) (2003) WTO Doc WT/DS244/AB/R (Appellate Body Report) para 81, [US - CorrosionResistant Steel Sunset Review]; European Communities — Selected Customs Matters (Complaint by United States) (2006) WTO Doc WT/DS315/AB/R (Appellate Body Report) para.133.

10 GATS Article I. 3 "measures by Members means measures taken by (i) central, regional or local governments and authorities; and (ii) non-governmental bodies in the exercise of powers delegated by central, regional or local governments or authorities".

11 US - Corrosion-Resistant Steel Sunset Review para.81.

12 Castro-Riberos p. 124.

13 European Communities — Regime for the Importation, Sale and Distribution of Bananas (Complaint by Ecuador, Honduras, Guatemala, Mexico, United States) (1997) WTO Doc WT/DS27/AB/R (Appellate Body Report) para.220.

14 Canada - Certain Measures Affecting the Automotive Industry (Complaint by Japan) (2000) WTO Doc WT/DS139/ $\mathrm{AB} / \mathrm{R}$ (Appellate Body Report) paras 151-152, 155, 159, 164-166; DIANA ZACHARIAS, "Article I GATS: Scope and Definition" in Ruideger Wolfrum, Peter-Tobais Stoll, \& Clemens Feinaugle, eds., Max Planck Commentaries on World Trade Law: WTO Trade in Services (Leiden- Boston: Martinus Nijhoff Publishers, 2008) 31 at 47 [Zacharias]. 
GATS commitments that are most likely to be inconsistent with prudential regulation in the banking sector are Most Favored Nation (GATS Article II) and National Treatment (GATS Article XVII). For example, all foreign banks or those established in a certain country could be subjected to less favorable treatment than that given to domestic banks, through the imposition of stringent conditions after assessing the inadequate or insufficient supervision of their host state, such as greater minimum capital requirements ${ }^{16}$.

The WTO's broad interpretation of the concepts "measure" and "affect" contribute to further enhance the prudential carve-out as a powerful provision. It can be used against any commitment in financial services, and cover a plethora of actions or omissions attributable to a State. This leads us to wonder the extent of its potency, the source of which is the term "prudential". Another factor that wakens our interest is the popularity this provision has achieved. Although WTO Members have yet to invoke it, they have not held back in rewriting it into their FTAs.

\section{TWO MAIN APPROACHES WHEN ESTABLISHING THE PRUDENTIAL CARVE-OUT EXCEPTION IN INTERNATIONAL LEGAL INSTRUMENTS}

Although the birthplace of the prudential carve-out is the GATS AFS it has reproduced itself outside of the WTO legal framework. In this process of replication the prudential carve-out has undergone mutations. Some of these mutations have brought it a more polished feel without significantly modifying it, while other mutations have given birth to prudential carve-out anomalies, or more specifically prudential carve-out ghosts. Through the first approach, taken by the United States, Canada, and Japan, the prudential carve out maintains its nature as a broad and strong exception ${ }^{17}$. Of course there are many other nations that have kept the phrasing and spirit of the GATS AFS carve out in their FTAs, but we focus on these three as the most potent representatives of the first approach.

The second is the European approach which strives for a weakened exception, moving away from the spirit of the GATS prudential carve-out. As the heavyweights of international trade, these nations are able to impose their approach on their treaty counterparts in varying degrees. However, when the European approach collides with the strong exception champions, the latter ones prevail.

The analysis that leads to this observation is based on some of the latest and most key FTAs signed by the United States, Japan, Canada, The European Union, and EFTA

We must first look at the original prudential carve-out. It is this prudential carveout that we will interpret through the customary rules of interpretation of international law, as this can also aide the understanding of the carve-outs incorporated in other legal instruments. 
2 (a) Notwithstanding any other provisions of the Agreement, a Member shall not be prevented from taking measures for prudential reasons, including for the protection of investors, depositors, policy holders or persons to whom a fiduciary duty is owed by a financial service supplier, or to ensure the integrity and stability of the financial system. Where such measures do not conform with the provisions of the Agreement, they shall not be used as a means of avoiding the Member's commitments or obligations under the Agreement ${ }^{18}$.

\section{a. The strong exception approach}

The only significant change found in the FTAs signed by the United States and Canada is a footnote after the term prudential reasons stating that these include "the maintenance of the safety, soundness, integrity, or financial responsibility of individual financial institutions or cross-border financial service suppliers" ${ }^{\prime 19}$. This shared wording originates in the NAFTA, where these objectives are squeezed in between protection of investors, depositors, etc., and ensuring the integrity and stability of the financial system ${ }^{20}$.

Regarding the original prudential carve-out in the GATS AFS, this footnote introduces further legitimate objectives that prudential measures may peruse concerning the stability and financial responsibility of individual financial institutions. However, the list of legitimate objectives in the GATS AFS carve-out is merely exemplary as it will be demonstrated in Section IV. Therefore the absence of a reference to institution specific objectives does not close the door to measures that pursue such objectives.

Japan has preferred to leave the prudential carve-out untouched, and even in its latest Economic Partnership Agreements (2014-2015), and the provision is an almost identical representation of the original GATS carve-out ${ }^{21}$. Consequently, the prudential carve-out as used by the United States, Canada and Japan, maintains the same spirit of being a strong and broad exception. It has been modernized to some extent by the United States and Canada through the introduction of exemplary legitimate objectives that center on the stability and responsibility of individual institutions. Yet as stated

GATS AFS Paragraph 2(a).

19 For example: Trade Promotion Agreement between the United States of America and the Republic of Panama, 28 June 2007, (entered into force 31 October 2012) Article 12(10); Trade Promotion Agreement between the United States of America and the Republic of Colombia, 22 November 2006, (entered into force 15 May 2012) Article 12(10), Free Trade Agreement between the United States of America and the Republic of Korea, 30 June 2007 (entered into force 15 March 2012) Article 12(10); Trade Promotion Agreement between Canada and Colombia, 21 November 2008 (entered into force 15 August 2011) Article 11(10); Free Trade Agreement between Canada and the Republic of Korea, 22 September 2015 (entered into force 1 January 2015) Article 10(10).

20 North American Free Trade Agreement, 17 December 1992 (entered into force 1 January 1994) Article 1410; also integrated into the exception without a footnote in the Free Trade Agreement between Canada and the Republic of Honduras, 5 November 2013 (entered into force 1 October 2014) Article 13(10).

21 Agreement between Japan and the Republic of Peru for an Economic Partnership, 31 May 2011 (entered into force 1 March 2012) Annex 7 Article 8; Agreement between Japan and Australia for an Economic Partnership, 8 July 2014 (entered into force 15 January 2015) Article 11.4; Agreement between Japan and Mongolia for an Economic Partnership, 10 February 2015 (not yet in force) Annex 4 Article 3. 
above, the absence of this mention would not mean that the GATS AFS prudential carveout would not cover such prudential reasons.

\section{b. The weak exception approach}

Discontent with the original strong and broad prudential carve-out has stemmed from Europe, and here we group the FTAs signed by the European Union and EFTA since we can identify a shared and almost identical approach. The origin of this discontent is most likely owed to Switzerland. As the first mayor dissenter of the GATS AFS carve-out, Switzerland was never quite comfortable with the broad and strong spirit that pleased most other WTO members, as will be evidenced in section IV(c). This seed of unconformity has spread to the rest of Europe.

The wording of the prudential carve-out in the European approach hopes to contain three interesting differences. These three elements escalade in transforming and limiting the strong and broad spirit of the original prudential carve out, and the presence of all three results in what was previously referred to as a prudential carve-out ghost. Natura1ly, European negotiators have not been successful in introducing all three elements in all of their FTAs. We will first present the three elements of the European approach and then refer to the FTAs which have managed to include them.

In the first place, in EFTA FTAs the measures taken for prudential reasons are expressly required to be "reasonable", a word absent in the AFS. This first distinctive element surely intends to limit the scope of the carve-out by expressly conditioning the prudential reasons to a standard of reasonability, which is in principle undefined. In spite of this, we will show how reasonability is carved into the AFS prudential carve-out's essence, so ultimately this first distinctive element does not significantly hinder the prudential carve-out.

The second element, present some European FTAs is by far the most innovative. Instead of the AFS prudential carve-out's final sentence stating that the carve-out must not be used to circumvent obligations under the agreement, the limitation is much more solid. A measure would not be prudential if it's more burdensome than necessary to achieve its purpose. Although not a stranger to the WTO, this "not more burdensome than necessary" requirement is not present in the wording of the AFS prudential carve-out. In section IV(c) it will be demonstrated how the application of such a standard to the AFS prudential carve-out would be quickly discarded by many WTO Members.

This requirement is interesting because it employs a familiar WTO standard, undoubtedly giving more weight to the goal of liberalization but still allowing for regulatory space. Some may see the introduction of this standard as a middle-ground, and compared to the final element it very well could be. Although the not more burdensome than necessary standard significantly handicaps the original spirit of the prudential carve-out, the third element of the European approach implies total paralysis.

In a few FTAs the UE and EFTA have managed to introduce this third element. It mandates that prudential measures must not discriminate against financial services or financial service suppliers of another Party in comparison to the Party's own like financial servi- 
ces or like financial service suppliers (National Treatment). In short, national treatment obligations are not carved out in these FTAs ${ }^{22}$. This last element is what turns these prudential carve-outs into carcasses as they cannot be used to discriminate, when the main obligation is precisely non-discrimination. In fact, when analyzing the negotiating history of the GATS AFS prudential carve-out we will see that National Treatment was the main commitment many Members had in mind when drafting the prudential carve-out.

As mentioned above, the entirety of the European approach has not prevailed in every FTA. The EPA between Japan and Switzerland stays entirely true to the GATS AFS carve-out, ignoring the word "reasonable", along with the Swiss Model's entire second paragraph. Instead it employs the traditional warning against abusing the prudential carve-out ${ }^{23}$.

In EFTA's FTA with Singapore ${ }^{24}$, the second paragraph's prohibition of discrimination is limited to a discrimination of an unjustifiable or arbitrary nature. In the EFTA FTA with the Republic of Korea ${ }^{25}$, the carve out follows the GATS' AFS provision, but includes a final phrase establishing the requirement that such measures shall not be more burdensome than necessary. The wording of the carve-out in the EFTA-Singapore and EFTA-Korea FTAs is much more reasonable, manifesting a clear will towards a more restricted and narrow approach, without negating the possibility to discriminate altogether. Weaker negotiators have succumbed to accepting the three elements, which can be found in the EFTA-Colombia, EFTA-Mexico and EFTA-Central American FTAs ${ }^{26}$.

The same pattern can be observed in the European Union's FTAs. For example, the prudential carve-out in the European Union - Singapore FTA includes the word "reasonable", and the second paragraph establishes the "not more burdensome than necessary" requirement. However, the prohibition of discrimination is conditioned to that of an unjustifiable or arbitrary nature ${ }^{27}$. In the European Union - Korea FTA, only the "not more burdensome than necessary" element has been introduced ${ }^{28}$. Again, weaker nego-

23 Agreement on Free Trade and Economic Partnership between Japan and the Swiss Confederation, 19 Februrary 2009 (entered into force 1 September 2009) Annex VI Article VI(1).

24 Free Trade Agreement between the EFTA States and Singapore, 26 June 2002 (entered into force 1 January 2003) Annex VIII Article 3 (1)(2).

25 Free Trade Agreement between the EFTA States and the Republic of Korea, 15 December 2005 (entered into force 1 September 2006 for Norway, Liechtenstein and Switzerland; 1 October 2006 for Iceland) Article 4.8(2).

26 Free Trade Agreement between the Republic of Colombia and the EFTA States, 25 November 2008 (entered into force 1 July 2011 for Colombia, Lichtenstein, and Switzerland; 1 September 2014 for Norway; 1 October 2014 for Iceland) Annex XVI Article 6.1; Free Trade Agreement between the EFTA States and Mexico, 27 November 2000 (entered into force 1 July 2001) Article 36; Free Trade Agreement between the EFTA States and the Central American States, June 242013 (entered into force 19 August 2014 for Costa Rica, Panama and Norway; 29 August 2014 for Liechtenstein and Switzerland; 5 September 2014 for Iceland) Annex XVII, Article 5(1)(2).

27 Free Trade Agreement between the European Union and Singapore, Negotiations Concluded 17 December 2012 (not yet in force) Article 8.50.

28 Free Trade Agreement between the European Union and the Republic of Korea, 15 October 2009 (entered into force 1 July 2011) Article 7.38. 
tiators have accepted prudential carve-out provisions containing all three elements, as can be seen in the European Union - Mexico FTA and the European Union - Colombia and Peru FTA 29 .

\section{c. When the approaches meet}

The European or weak exception approach has led to head-butting with the heavy-weight sympathizers of the classically broad prudential carve out. Negotiations with Canada for the Canada-European Union: Comprehensive Economic and Trade Agreement (CETA) were held up due to these diverging positions regarding the prudential carve-out ${ }^{30}$. The prudential carve-out that has resulted from this clash of titans is one of a kind, and could be the first to see action in the front of dispute settlement. The following observations are based on leaked CETA texts ${ }^{31}$.

At a first glance the prudential carve-out in this FTA, found in Article 15.1 of the Chapter on Financial Services, seems ordinary except for the inclusion of the term "reasonable" to describe the measures. Article 15.3 allows the prohibition of a particular financial service or activity as long as it is transversal, respecting National Treatment and Most Favored Nation provisions, i.e. with no discrimination. However this prohibition cannot apply to all financial services or a complete sub-sector. What really makes this prudential carve-out stand out is its connection with Investor-State dispute settlement.

Article 20.1(b) of this Chapter, establishes that the provisions on Investor-State dispute settlement are also applicable to disputes in which the prudential carve-out is invoked. The respondent State has a few options when invoking the carve-out. It can refer the matter to the Financial Services Committee (FSC) for it to determine whether the prudential carve-out is a valid defense to the claim. If there is a joint determination by the FSC (or the CETA Trade Committee) that the prudential carve-out is a valid defense, the arbitral proceedings will be discontinued. The FSC could also find that the carve-out does not apply to the entirety of the claims, and proceedings may continue in that respect. The time limit for such determination is three months, after which arbitral proceedings will continue. The respondent State can also request the tribunal to decide on the application of the prudential carve-out as a preliminary matter.

This version of the prudential carve-out is much more likely to find its way into dispute settlement. Unlike the other variations of the prudential carve-out, the challen-

29 Trade Agreement between The European Union and its Member States, of the one part, and Colombia and Peru, of the other part, 26 June 2012 (entered into force 1 August 2013) Article 154; Economic Partnership, Political Coordination and Cooperation Agreement between the European Community and its Member States, of the one part, and the United Mexican States, of the other part, 8 December 1997 (entered into force 1 October 2000), Decision 2/2001 of the EU-Mexico Joint Council Article 19.

30 Heather Soffield, "EU, Canada's differences over financial services holding up free trade pact: documents" The Canadian Press (29 May 2013) (QL).

31 European Commission Directorate-General for Trade (Trade Policy Committee) "CETA Consolidated text" 5 August 2014, Brussels (QL). 
ging of measures taken for prudential reasons is not left to the political disposition of the contracting States and is open to investors.

Another clash of titans that could mold a new mutation of the prudential carve-out could come through the Transatlantic Trade and Investment Partnership (TTIP) between the European Union and the United States. There has been pressure by the European Banking Federation for the European Union to limit a classically broad prudential carve out $^{32}$. The European Union's leaked draft proposal on Trade in Services, Investment and Electronic Commerce of July $22013^{33}$ includes a "not more burdensome than necessary" requirement.

We can see through these examples, how Switzerland and the European Union aim at a restricted, caged and almost self-negating prudential carve-out, and are able to impose such wording on weaker or less convicted negotiators, while yielding to stronger negotiators on different levels. It also shows us how despite never having been invoked, the prudential carve-out can evolve.

\section{d. A foggy glimpse into the future with TISA}

The Trade in Services Agreement is an ambitious project launched in mid-2012 by a coalition of WTO members referred to as the "Really Good Friends" of services group (RGF). As a result of the deadlock in Doha Round Negotiations, after the $8^{\text {th }}$ Ministerial conference in December 2011 the United States and Australia lead a proposal that sought to advance plurilateral negotiations on services liberalization ${ }^{34}$. On July $5^{\text {th }} 2012$, the RGF group agreed to prepare negotiations on an international services agreement ${ }^{35}$. These negotiations launched in early 2013 and eight rounds have been held so far with the participation of 23 countries: Australia, Canada, Chile, Chinese Taipei, Colombia, Costa Rica, European Union (representing its 28 Member States), Hong Kong, Iceland, Israel, Japan, Liechtenstein, Mexico, New Zealand, Norway, Pakistan, Panama, Paraguay, Peru, Republic of Korea, Switzerland, Turkey and the United States, with the latest round

32 European Banking Federation "EBF position on the inclusion of financial services in the Transatlantic Trade and Investment Partnership negotiations" 7 June 2013, Brussels (EBF_002430) (QL).

33 European Commission Directorate-General for Trade (Trade Policy Committee: Services and Investment) "TTIP negotiations: Modified EU draft proposals on trade in services, investment and electronic commerce" 2 July 2013, Brussels. Article 32 (QL).

34 Pierre Suavé, "A Plurilateral Agenda for Services? Assessing the case for a Trade in Services Agreement (TISA)" (2013) NCRR Trade Regulation (QL); See also PIERRE SuAVÉ, "The Plurilateral Agreement on Services" (2013) European Parliament-Directorate General for External Policies p. 6. (QL); GARY CLYDE Hufbauer, Bradford Jensen \& Sherry Stephenson, "Framework for the International Services Agreement" (2012) Peterson Institute for International Economics (QL); ICTSD, "Services Openings Eyed by some WTO Members" 16(9) Bridges Weekly Trade News Digest (7 March 2012) pp. 5-6. (QL).

35 Australian Government Department of Foreign Affairs and Trade, Press Release "Advancing Negotiations on services" (5 July 2012) (QL); Office of the United States Trade Representative, Press Release "Advancing Negotiations on Trade in Services" (5 July 2012) (QL). 
planned for December 2014 ${ }^{[36]}$. Do these revolutionary negotiations hold revolutionary changes to the prudential carve out?

The most likely outcome is that they won't. The following is the drafted text of TISA's Financial Services Annex between the $5^{\text {th }}$ and $6^{\text {th }}$ rounds of negotiations, with the consolidation of texts as of April 14 2014. This is a classified document, meant to be disclosed only 5 years after the agreement's entry into force, or after the close of negotiations; however it has been leaked by Wikileaks.

1. Notwithstanding any other provision of the Agreement, a Party shall not be prevented from [PA, EU: taking] [US: adopting or maintaining] measures for prudential reasons, including for: (a) the protection of investors, depositors, [PA, US financial market users], policy-holders or persons to whom a fiduciary duty is owed by a financial service supplier; or (b) to ensure the integrity and stability of a Party's financial system.

2. Where such measures do not conform with the provisions of this Agreement, they shall not be used as a means of avoiding the Party's commitments or obligations under the Agreement ${ }^{37}$.

As can be clearly evidenced, there is nothing revolutionary about this prudential carve-out, in fact it is almost identical, word for word, with the GATS'AFS prudential carve out. Together with the analysis in section V regarding the Member States' will in determining the prudential cave-out's content in the Committee on Financial Services, this is evidence of the somewhat general state of conformity with the provision's current wording. We must take into account that although not a WTO Agreement, the TISA promoters aim to offer participation to other WTO Members and maintaining consistency with the familiar and original wording of the GATS is convenient for that purpose. Yet beyond this consideration, it seems that the European desire for a restrictive prudential carve-out has no hope of materializing in a plurilateral agreement like TISA, which involves several powerful sympathizers of the broad approach like Canada, the United States, and Japan.

\section{e. A traditional pattern in the listed legitimate objectives common to both approaches}

A common feature in both the strong and weak exception approaches is that the legitimate objectives are still listed in an illustrative, non-exhaustive, manner as set forth by the expressions "including", and "such as". Consequently, the fact that the protection of a particular type of entity is not listed as a legitimate objective, does not mean that a measure taken for its protection would fall outside the scope of the carve-out. However, if we compare the legitimate objectives that are indeed illustrated, we can observe that

36 Australian Government Department of Foreign Affairs and Trade, Trade in Services Agreement, (QL).

37 Trade in Services Agreement country negotiators, "Trade in Services Agreement (TISA) Annex [X]: Financial Services, Consolidation of text proposals" (14 April 2014) (Released by Wikileaks on June 19 2014) Article X.17: Prudential Measures. 
the express mention of non-institutional actors refers to financial consumers that are in some way creditors, as opposed to debtors, of the financial system (investors, depositors, holders or beneficiaries of an insurance policy, etc.).

In Latin America there seems to be a trend to move away from that general pattern, which is naturally not imposed on mightier trading partners from the northern hemisphere, but can be found in the FTAs signed between these nations. Colombia, Mexico and Costa Rica tend to include the protection of takers of funds as a legitimate objective ${ }^{38}$. The prudential carve-out in the Colombia-Costa Rica FTA reaches the broadest point including the protection of all financial market participants as a legitimate objective.

The non-inclusion of these actors does not necessarily mean that the protection of other financial services consumers would not be a legitimate objective, especially since such protection is present in domestic law. For example for financial consumers that are debtors to the financial system the right to receive objective information on the access to financial services and products tends to be present in domestic regulation ${ }^{39}$. There can even be less traditional objectives. One of the most peculiar is found in the United States where the Community Affairs unit of the Bureau of Financial Consumer Protection, established in Section 1011 of the Dodd-Frank, is tasked with "providing information, guidance, and technical assistance regarding the offering and provision of consumer financial products or services to traditionally underserved consumers and communities ${ }^{\prime \prime} 40$ In general, the protection of financial services consumers not traditionally listed in prudential carve-out still constitutes a preoccupation for countries ${ }^{41}$.

However, the trend in the legitimate objectives that are listed in the prudential carveout provisions does prove that more attention is given to the protection of consumers that have trusted funds to the financial system. Consequently, in section VII when exemplifying how a WTO Panel could demystify the prudential carve-out we will work with the legitimate objective of depositor protection which is found in all of the prudential carve-out provisions we have cited. This is without prejudice that the same can be done for all of the legitimate objectives listed in these provisions.

38 Tratado de Libre Comercio entre los Estados Unidos Mexicanos y la República de Colombia, 13 June 1994 (entered into force 1 January 1995) Article 12 (09); Acuerdo de Libre Comercio entre la República de Colombia y la República de Costa Rica, 22 May 2013 (not yet in force) Article 14.10.

39 For example throughout the Pacific Alliance, Chile: Ley 19.496 (1997) Article 3, modified by Ley 20.555 (2011) Article 1.; Colombia Ley 1328 (2009) Articles 5,6.; Mexico Ley Federal de Protección al Consumidor (1992) Articles 7,7BIS.; Ley de Protección y Defensa al Usuario de Servicios Financieros Articles 52,53; Peru Ley 29.571 Código de Protección y Defensa al Consumidor (2010) Article 1.1(b).

40 Dodd-Frank Wall Street Reform and Consumer Protection Act, Pub. L. n. ${ }^{\circ} 111-203,(2010) \$ 1013$ b. (2); Authors like Allen \& Herring consider that broader social objectives, like the facilitation of home ownership, provide justification for many other regulations aside from the traditional justifications such as the avoidance of financial crises, see: Franklin Allen \& Richard Herring, "Banking Regulation versus Securities Market Regulation" (2001) Wharton School University of Pennsylvania, p. 1.

41 For example, there is a G20-OECD task force for the implementation of the G20 High Level Principles on Financial Consumer Protection, (October 2011) containing principles like Disclosure and Transparency, and Financial Education and Awareness. 


\section{INTERPRETING THE PRUDENTIAL CARVE-OUT IN ACCORDANCE WITH INTERNATIONAL LAW'S CUSTOMARY RULES OF INTERPRETATION}

Despite how obscure or ambiguous a Treaty's provision may be, there is consensus on the method that should be employed when interpreting it. The International Law Commission (ILC) sought to identify the general principles of law that governed treaties, including the rules of treaty interpretation that had taken form as customary international law $^{42}$. By 1966 it had compiled these rules, identified in PCA, ICJ and PCIJ decisions ${ }^{43}$, in its Draft Articles on the Law of Treaties, in Article 27, general rule of interpretation, and Article 28, supplementary means of interpretation ${ }^{44}$. Based on this work, the General Assembly through Resolution 2166 (XXI) of December $1966^{45}$, convened an international conference of plenipotentiaries to consolidate the work into a treaty. On May 22 1969, the Conference adopted the Vienna Convention on the Law of Treaties (VCLT), whose articles 31 and 32 enshrine the general and supplementary rules of treaty interpretation.

The ICJ has recognized the rules enshrined in VCLT Articles 31 and 32 as constituting customary international $\mathrm{law}^{46}$ and in the context of the WTO the Appellate Body has done the same ${ }^{47}$. This is particularly important given that Article 3.2 of the Dispute Settlement Understanding (DSU) states that the WTO's dispute settlement mechanism

42 Ian Brownlie, Principles of Public International Law (New York: Oxford University Press, 2008 ) p. 632. [Brownlie].

43 For example: Case Concerning Rights of Nationals of The United States of America in Morocco (France v United States) Judgment of August 27 1952, [1952] ICJ Rep 176, pp. 196,199 [us Nationals in Morocco]; Competence of the ILO in regard to International Regulation of the Conditions of the Labour of Persons Employed in Agriculture "Advisory Opinion" (12 August 1922) PCI Series B n. ${ }^{\circ}$ 2, 9, p. 23; Ambatielos Case (Greece v United Kingdom) Preliminary Objection, [1952] ICJ Rep 28, p. 44; Russian Claim for Interest on Indemnities (Russia v Turkey) "Award of the Tribunal" (11 November 1912) (Unofficial English Translation) The Hague, p. 3; Corfu Channel Case (United Kingdom v Albania) Judgment of 9 April 1949 [1949] ICJ Rep 2, p. 25; Legal Status for Eastern Greenland "Judgment" (5 April 1933) PCIJ Series A/B n. ${ }^{\circ}$ 53, 22, p. 49.; Polish Postal Service in Dazing "Advisory Opinion" (16 May 1925) PCIJ Series B n. ${ }^{\circ} 11,4$, p. 39.

44 International Law Commission, "Draft Articles on the Law of Treaties with Commentaries" (1966) Il Yearbook of the International Law Commission.

45 International conference of plenipotentiaries on the law of treaties, GA Res 2166 (XXI), UNGAOR, $1484^{\text {th }}$ plenary meeting (1966).

46 For example Territorial Dispute Case (Libyan Arab Jamahiririya v Chad) Judgment of 3 February 1994 [1994] ICJ Rep 4, para.41; Oil Platforms Case (Islamic Republic of Iran v United States) Judgment of 6 November 2003 [2003] ICJ Rep 161, para.41; Case Concerning Kasikili/Sedudu Island (Botswana v Namibia) Judgment of 13 December 1999 [1999] ICJ Rep 1045, para.18; MALCOM D. EvANS, International Law (New York: Oxford University Press, 2010) p. 184. [Evans].

47 United States — Standards for Reformulated and Conventional Gasoline (Complaint by Bolivarian Republic of Venezuela) (1996) WTO Doc WT/DS2/AB/R (Appellate Body Report) para 17, [US-Gasoline]; Japan — Taxes on Alcobolic Beverages para 10; United States - Sections 301-310 of the Trade Act 1974 (Complaint by European Communities) (1999) WTO Doc WT/DS152/R (Panel Report) para.7.21.; United States — Anti-Dumping Measures on Certain Hot-Rolled Steel Products from Japan (Complaint by Japan) (2001) WTO Doc WT/DS184/AB/R (Appellate Body Report) para.60 [US - Hot Rolled Steel]. 
must clarify the provisions contained in the covered agreements in accordance with customary rules of interpretation of public international law ${ }^{48}$.

Although applying these rules to the prudential carve-out provision will not magically consolidate its elusiveness with a tangible content, it will provide perspective. Through this method we can understand the will of its creators, the reasons behind its current state, and the conflict of principles that it embodies.

\section{a. The Prudential Carve-Out interpreted in its literal sense, context, and purpose}

The general rule of interpretation mandates that "[a] treaty shall be interpreted in good faith in accordance with the ordinary meaning to be given to the terms of the treaty in their context and in the light of its object and purpose ${ }^{\prime \prime 4}$. Given that there are three official languages in the WTO, we can attempt to triangulate the ordinary meaning of "prudential", as each text is equally authoritative ${ }^{50}$.

\section{i. Interpretation of the term "prudential" in its ordinary meaning and context}

The Merriam-Webster Dictionary defines prudential as: "exercising prudence especially in business matters", and prudence as: "careful good judgment that allows someone to avoid danger or risks" ${ }^{\prime \prime}$.

The Real Academia de la Lengua Española defines "cautelar" as: "1. Preventivo, precautorio; 2. Dicho de una medida o de una regla destinada a prevenir la consecución de determinado fin o precaver lo que pueda dificultarlo"52. "Prudencial" is defined as 1 . Perteneciente o relativo a la prudencia. 2. Que no es exagerado ni excesivo" ${ }^{\prime \prime 3}$.

The Larousse defines "prudence" as: "Attitude de quelqu'un qui est attentif à tout ce qui peut causer un dommage, qui réfléchit aux conséquences de ses actes et qui agit de manière à éviter toute erreur". And "prudent/prudente" as "Qui fait preuve de prudence, de circonspection dans ses actes, de grande attention dans les situations qui comportent des dangers" ${ }^{\prime \prime}$

Although in Colombia's FTAs the term "cautelares" found in the Spanish AFS prudential carve-out has been replaced by "prudenciales", we can see that the original term is richer in content and more compatible with the English and French definitions of "prudential". Present in the three definitions, is the idea of upcoming circumstances, and the need of thinking/acting ahead to avoid the occurrence of particular harm. One

Understanding on Rules and Procedures Governing the Settlement of Disputes, 1869 U.N.T.S. 401, Article $3.2[D S U]$.

49 Vienna Convention on the Law of Treaties, 23 May 1969, 1155 unTs 331; 8 ILM 679, Article 31.1 [VCLT].

50 VCLT Article 33.1.

51 Merriam-Webster Dictionary (Merriam-Webster.com) sub verbo "prudence"

52 Diccionario de la lengua española (22. Ed. Rae.es) sub verbo "cautelar".

53 Diccionario de la lengua española (22. Ed. Rae.es) sub verbo "prudencial".

54 Larouse (Larouse.fr) sub verbos "prudence" "prudent/prudente". 
must not, however, equate the dictionary definitions with the ordinary meaning of the terms under analysis. Although this approach is a good place to start, as noted by the Appellate Body in several occasions, dictionaries are not sufficient in resolving complex questions of interpretation ${ }^{55}$.

The concept of preventing the occurrence of a certain harmful situation harmonizes perfectly with the context ${ }^{56}$ surrounding the term "prudential". The provision is drafted in a way that allows the existence of measures for prudential reasons, in spite of the obligations that have been established throughout the agreement. Some see the prudential carve-out as an exception, a clause that legitimizes a behavior that would otherwise be contrary to the commitments acquired in the agreement ${ }^{57}$. Others maintain that through these measures there is no violation to the contracted obligations in the first place, as the provision "carves-out" or withdraws such measures from the agreement's scope of application and its substantive obligations ${ }^{58}$. Another approach focusing on the technique of legal drafting, can center its attention on the term "notwithstanding", which attributes the clause greater priority than the rest, rendering any clauses it may overlap, or conflict with, as none-existent ${ }^{59}$.

In any case, the objective of protecting investors, depositors, policy holders, and creditors of fiduciary duties, and the integrity and stability of the system as a whole, is regarded as crucial enough for prudential measures to ignore, or justify the inobservance of, GATS obligations. However, the carve-out expressly warns against abusing the right to take such measures as their purpose cannot be the none-compliance of GATS obligations. The WTO has touched on the abuse of rights doctrine. In US - Shrimp the Appellate Body stated that as an expression of the principle of good faith, this doctrine "prohibits the abusive exercise of a state's rights and enjoins that whenever the assertion of a right 'impinges on the field covered by [a] treaty obligation, it must be exercised bona fide,

55 United States - Measures Affecting the Cross-Border Supply of Gambling and Betting Services (Complaint by Antigua y Barbuda) (2005) WTO Doc WT/DS285/AB/R (Appellate Body Report) para.164 [US - Gambling]; United States - Final Countervailing Duty Determination with respect to certain Softwood Lumber from Canada (Complaint by Canada) (2004) WTO Doc WT/DS257/AB/R (Appellate Body Report) para.59 [US - Softwood Lumber IV]; Canada - Measures Affecting the Export of Civilian Aircraft (Complaint by Brazil) (1999) WTO Doc WT/DS70/AB/R (Appellate Body Report) para. 153; European Communities — Measures Affecting Asbestos and Products Containing Asbestos (Complaint by Canada) (2001) WTO Doc WT/DS135/AB/R (Appellate Body Report) para.92; China - Measures Affecting Trading Rigbts and Distribution Services for Certain Publications and Audiovisual Entertainment Products (Complaint by United States) (2009) WTO Doc WT/DS363/AB/R (Appellate Body Report) para. 348 [China - Publications].

56 Argentina - Safeguard Measures on Imports of Footwear (Complaint by European Communities) (1999) WTO Doc WT/DS121/AB/R (Appellate Body Report) para.81, footnote 72; United States - Subsidies on Upland Cotton (Complaint by Brazil) (2005) WTO Doc WT/DS267/AB/R (Appellate Body Report) paras.549-550; Korea Definitive Safeguard Measure on Imports of Certain Dairy Products (Complaint by European Communities) (1999) WTO Doc WT/DS98/AB/R (Appellate Body Report) para. 81.

57 Castro-Riberos pp. 136-138; Bogdandy \& Windsor p. 634.

58 WTO Doc, S/FIN/W/73 Background Note by the Secretariat (3 February 2010) para.29.

59 Kenneth A. Adams, "Drafting Matters" NY. Lw. Jrnl. Backpage (5 July 5 2002) (QL). 
that is to say, reasonably"'60. Therefore, we can see how a measure's possible incongruities with GATS commitments are accepted as collateral damage provided that there is a "reasonable means to ends connection" with the prudential reason ${ }^{61}$.

As recognized by the Appellate Body in India - Patents, the principles of treaty interpretation enshrined in VCLT Article 31 "neither require nor condone the imputation into a treaty of words that are not there or the importation into a treaty of concepts that were not intended"62. Therefore we must be careful not to introduce alien concepts into the prudential carve-out, despite their familiarity. Examples of such concepts are precisely those that Switzerland, the European Union, and Israel, have introduced in their FTA prudential carve-outs as seen above. Terms like: "not more trade restrictive than necessary", found in the SPS and TBT agreements ${ }^{63}$ or "not more burdensome than necessary", found in GATS VI. 4 as criteria for domestic regulation, are absent in the prudential carve out. Moreover, the prudential carve out differs significantly from the GATS general exception in Article XIV that requires the Member to prove the necessity of a measure for its application ${ }^{64}$. We should therefore overcome the temptation of supplementing the nonexistent case law on the prudential carves out, with the ample jurisprudence on such standards ${ }^{65}$.

Interpretation in the literal sense may seem to be obvious or a waste of time, and indeed in several occasions it can be a dull and unchallenging exercise. However, the result of a mediocre or lacking literal interpretation can lead to horrendous interpretations and astoundingly ridiculous claims. To exemplify, let us observe the following claim regarding the GATS prudential carve-out:

As the second sentence makes clear, the provision may only be used to defend regulatory policies if such policies do not undermine the commitments and obligations established through the other WTO rules. This effectively eviscerates the use of the provision to protect

60 United States - Import Probibition of Certain Shrimp and Shrimp Products (Complaint by India, Malaysia, Pakistan, Thailand) (1998) WTO Doc WT/DS58/AB/R (Appellate Body Report) para.158, footnote 156 [US - Shrimp] citing CHENG, B. "General Principles of Law as applied by International Courts and Tribunals" (1953) Stevens and Sons Ltd. p. 125.

61 Castro-Riberos p. 141.

62 India - Patent Protection for Pharmacentical and Agricultural Chemical Products (Complaint by United States) (1997) WTO Doc WT/DS50/AB/R (Appellate Body Report) para.45.

63 Agreement on the Application of Sanitary and Phytosanitary Measures, 1867 U.N.T.S. 493, Article 5.6 [SPS]; Agreement on Technical Barriers to Trade, 1868 U.N.T.S. 120, Article 2.2 [TBT].

64 GATS Article XIV; see also Yokoi-Arai p. 624.

65 For example: Australia - Measures Affecting Importation of Salmon (Complaint by Canada) (1998) WTO Doc WT/ DS18/AB/R (Appellate Body Report) para.194; Japan - Measures Affecting Agricultural Products (Complaint by United States) (1999) WTO Doc WT/DS76/AB/R (Appellate Body Report) para.95; Korea - Measures Affecting Imports of Fresh, Chilled and Frozen Beef (Complaint by United States) (2000) WTO Doc WT/DS161/AB/R (Appellate Body Report) para. 161; Brazil — Measures Affecting Imports of Retreaded Tyres (Complaint by European Communities) (2007) WTO Doc WT/DS332/AB/R (Appellate Body Report) paras.145-146; United States - Measures Concerning the Importation, Marketing and Sale of Tuna and Tuna Products (Complaint by Mexico) (2012) WTO Doc WT/DS381/AB/R (Appellate Body Report) paras.318-320. 
domestic regulatory policies that a country may have in place or may newly implement from WTO challenge ${ }^{66}$.

The authors have interpreted the final sentence of the provision, which warns against abusing the right to adopt prudential measures, as a negation to the right itself, rendering the provision meaningless and useless. Nothing could be farther from the correct interpretation of the prudential carve-out. Granted, the quoted article far from perusing academic correctness is centered on promoting a political discourse, but the root of the error is a failed interpretation of the literal terms in their context. The context comprises the entire text of the treaty and includes the preamble ${ }^{67}$ which in this case is a particularly helpful aide in our interpretation.

\section{ii. The Prudential Carve-Out in light of the Object and Purpose of the GATS}

A treaty's preamble may shed light as to its object and purpose: "[ $\mathrm{t}]$ he preamble is a principle and natural source from which indications can be gathered of a treaty's objects and purpose $^{\prime 68}$. International tribunals have made substantial use of it ${ }^{69}$ and the Appellate Body is no exception ${ }^{70}$. The Appellate Body has also emphasized that the "object and purpose" of the VCLT's Article 31.1 refers to the treaty as a whole, not specific provisions, although the "object and purpose" of a specific provision should harmonize with the object and purpose of the entire treaty ${ }^{71}$. With this in mind, the analysis of three paragraphs of the GATS preamble reveals two clear goals: the wish for progressive liberalization (Paragraph 2), and the recognition of the Members' right to regulate in order to meet national policy objectives (Paragraph 4).

66 Todd Tucker \& Lori Wallach, "No Meaningful Safeguards for Prudential Measures in the World Trade Organization's Financial Service Deregulation Agreements" (2009) Public Citizen, (QL) p. 5.

67 VCLT Article 31.2.

68 Case Concerning the Arbitral Award of 31 July 1989 (Guinea-Bissau v Senegal) Judgment of 12 November 1991 Dissenting Opinion of Judge Weeramantry [1991] ICJ Rep 130 p. 142; see also MITCHEL p. 33; Holger Hestermeyer, "Preamble Gats" in Ruideger Wolfrum, Peter-Tobais Stoll, \& Clemens FEINAugle, eds., Max Planck Commentaries on World Trade Law: WTO Trade in Services (Leiden- Boston: Martinus Nijhoff Publishers, 2008) 17, p. 19 [Hestermeyer].

69 Us Nationals in Morocco p. 196; Asylum Case (Colombia v Peru) Judgment of 20 November 1950 [1950] ICJ Rep 266, p. 282, Case Concerning the Beagle Channel (Argentina v Chile) "Award of the Tribunal" (18 February 1971) 57, para. 19.

70 US-Softwood Lumber IV para.64; Argentina - Measures Affecting Imports of Footwear, Textiles, Apparel and other Items (Complaint by United States) (1998) WTO Doc WT/DS56/AB/R (Appellate Body Report) para 47; US - Gambling paras. 188-189; US - Shrimp para. 153.

71 European Communities — Customs Classification of Frozen Boneless Chicken Cuts (Complaint by Brazil) (2005) WTO Doc WT/DS269/AB/R (Appellate Body Report) paras.238-239. 


\begin{tabular}{|l|l|}
\hline \multicolumn{1}{|c|}{ Preamble Paragraph 2 } & \multicolumn{1}{|c|}{ Preamble Paragraph 4 } \\
\hline $\begin{array}{l}\text { Wishing to establish a multilateral framework } \\
\text { of principles and rules for trade in services with } \\
\text { a view to the expansion of such trade under } \\
\begin{array}{l}\text { conditions of transparency and progressive } \\
\text { liberalization... }\end{array}\end{array}$ & $\begin{array}{l}\text { Recognizing the right of Members to regulate, } \\
\text { and to introduce new regulations, on the supply } \\
\text { of services within their territories in order to } \\
\text { meet national policy objectives... }\end{array}$ \\
\hline
\end{tabular}

Preamble Paragraph 3

Desiring the early achievement of progressively higher levels of liberalization of trade in services through successive rounds of multilateral negotiations aimed at promoting the interests of all participants on a mutually advantageous basis and at securing an overall balance of rights and obligations, while giving due respect to national policy objectives.

Paragraph three reveals the desire to balance both concepts. The balancing of these two objectives, progressive liberalization and regulatory space for national policy objectives could be seen as a greater objective in of itself.

Progressive liberalization in the GATS has been recognized as a principle by Appellate Body in China - Publications and Audiovisual Products stating:

The principle of progressive liberalization is reflected in the structure of the GATS, which contemplates that WTO Members undertake specific commitments through successive rounds of multilateral negotiations with a view to liberalizing their services markets incrementally... ${ }^{72}$

In the same report, the Appellate Body regarding the Members' right to regulate states "WTO Members' regulatory requirements may be WTO-Consistent in one of two ways. First, they may simply not contravene any WTO obligation. Secondly, even if they contravene a WTO obligation, they may be justified under an applicable exception"173. Seeking to debunk myths and falsehoods about the GATS, the WTO Secretariat has explained that "the right to regulate is one of the fundamental premises of the GATS" and that "the right to regulate and to introduce new regulations is explicitly guaranteed in the GATS, and that the GATS has no power to abolish regulation"74.

As evidenced, both of these objectives clearly intend to permeate the legal framework of the GATS. In the preamble they abide harmoniously ${ }^{75}$, and striking this balance can also been as one of the treaty's purposes in Paragraph Three. The challenge is therefore maintaining that balance in our interpretation of the prudential carve-out. We can see the right to regulate in the wording, and mere existence of, the prudential carve-out. We can also see the objective of progressive liberalization in its final sentence that warns against abusing such right with the purpose of avoiding contracted commitments. 


\section{b. Recourse to Supplementary Means of Interpretation}

Recourse to supplementary means of interpretation is undertaken for one of two reasons. On the one hand, when the primary rule still leaves the meaning ambiguous or leads to absurd results ${ }^{76}$, or to confirm the meaning resulting from applying the general rule ${ }^{77}$. Had the authors of the previously discussed absurd interpretation of the prudential carve-out by Public Citizen sought recourse to this aide, their unreasonable result would have been corrected. Our interpretation following the general rule has not lead to contradictions, yet the scope of the provision is not entirely clear. We can draw a few assertions:

- The prudential reasons that inspire the taking of measures covered by the carveout are considered important enough to merit creating a safeguard clause specifically for financial services, unlike any other in the WTO context, which does not incorporate frequently used standards such as: necessity, not more burdensome than necessary or least trade restrictive tests.

- Such prudential reasons enable the measures covered by the carve-out to ignore or not comply with acquired commitments despite all other provisions in the treaty.

- The prudential reasons are not listed exhaustively but include examples of financial services consumers that are creditors of the system (traditional approach), and the integrity and stability of the financial system as a whole. This does not mean that the protection of financial services consumers of another nature could not be a legitimate objective since domestic regulations evidence concern towards them as well.

- The concept of "prudential" is linked to an idea of thinking/acting ahead to avoid certain harmful circumstances.

- The concept of abus de droit is present in the provision and measures undertaken cannot be used to avoid GATS commitments, remaining genuinely linked to the prudential reasons through a reasonable means to ends connection.

- The prudential carve-out is does not contain elements that configure the chapeau of other WTO exceptions like the terms "necessary" and "not more burdensome than necessary".

- The prudential carve-out provision reflects two GATS objectives/principles, progressive liberalization and the right to regulate, and the desire to find balance between them.

76 VCLT Article 32; Canada - Measures Affecting the Importation of Milk and the Exportation of Dairy Products (Complaint by United States) (1999) WTO Doc WT/DS103/AB/R (Appellate Body Report) para.138; EC - Computer Equipment para.86; US - Gambling para.197.

77 United States - Countervailing Duties on Certain Corrosion-Resistant Carbon Steel Flat Products from Germany (Complaint by European Communities) (2002) WTO Doc WT/DS213/AB/R (Appellate Body Report) paras.89-90; China - Measures Affecting the Protection and Enforcement of Intellectual Property Rigbts (Complaint by United States) (2009) WTO Doc WT/DS362/R (Panel Report) para.7.260; see also Evans p. 186. 
Analyzing the prudential carve-out through the supplementary means of interpretation serves to confirm these claims and clarify the will of the Members regarding the balance between the right to regulate and progressive liberalization in the prudential carve-out.

\section{c. Preparatory Works: The initial positions regarding the wording of the exception in the context of the negotiations for the creation of the WTO}

Analyzing the drafting history of the covered agreements has been useful to the Appellate Body ${ }^{78}$. It provides a window into the conflicting interests and positions of the Members and the process of how consent was ultimately reached. The negotiating history of the prudential carve-out in the AFS is rich in detail as the nature of the issue was, and is, sensitive to the Members.

The Group of Negotiations on Services (GNS) of the Multilateral Trade Negotiations (MTN) during the Uruguay Round developed the prudential carve-out during the second semester of 1990 . The inclusion of a prudential carve-out provision was not debated since every delegation recognized the importance of establishing such a clause in the agreement. The discussion centered on the content of the prudential carve-out, which would determine the limits of a State's right to regulate.

Initially, there were five possible ways in which such a provision could be established, ranging from a broad to a narrow scope:

1. The first option was to incorporate the concept in a qualified national treatment provision.

2. The second option allowed all prudential measures to the extent that they were reasonable.

3. A third option, building up on the previous one, proposed the inclusion of permissible measures, not as an exhaustive list but rather as examples.

4. The radically broad fourth option sought an unqualified right to adopt such measures.

5. Lastly, a fifth option, seeking to reduce legal uncertainty to minimum, aimed at a precise definition of permitted prudential actions ${ }^{79}$.

The first option, which limited the prudential carve-out to a qualified national treatment provision was quickly discarded the great majority of delegations. For India, prudential regulations "cut across" the entirety of subjects discussed by the GNS ${ }^{80}$. The European Communities stated that prudential regulation was also compatible to the rest of the

Canada - Certain Measures Concerning Periodicals (Complaint by United States) (1997) WTO Doc WT/DS31/AB/R (Appellate Body Report) paras.33-34.; India - Quantitative Restrictions on Imports of Agricultural, Textile and Industrial Products (Complaint by United States) (1999) WTO Doc WT/DS9O/AB/R (Appellate Body Report) para.94; United States - Definitive Safeguard Measures on Imports of Circular Welded Carbon Quality Line Pipe from Korea (Complaint by Korea) (2002) WTO Doc WT/DS202/AB/R (Appellate Body Report) paras.171-175.

79 WTO Doc, MTN.GNS/FIN/1 Note on the Meeting of 11-13 June 1990 (5 July 1990) para.78 [MTN.GNS/FIN/1].

80 Ibid., para. 81 
agreements provisions for instance most favored nation treatment, and access to markets $^{81}$. Likewise, Canada held that it was "extremely important" to have prudential provisions that allowed governments and regulators to take the actions required to protect their markets. In this sense, there was no reason for the provision to apply exclusively to national treatment, and should be extended to any other provision in the agreement ${ }^{82}$. Only the Australian delegation considered option one as viable, however it also was inclined towards the second one ${ }^{83}$.

Following the consensus on discarding the first option, we can identify three main stances taken by the delegations. In the first place, those which promoted the precisely defined scope of the fifth option like Switzerland and South Africa. Secondly, those which advocated for a strong right of regulation and the greatest degree of discretion for adopting prudential measures, like the SEACEN countries. And lastly, a significant majority that aimed for the middle ground provided by the second option.

Defending the fifth option, Switzerland stressed that conflicts arising from the application of regulation should be subjected to dispute settlement, and consequently discarded the unqualified right to regulate proposed by the fourth option. The dispute settlement mechanism however, would be burdened by the reasonableness test of the second option. The broad approach of the second option would also be detrimental to the legal certainty increasingly sought for by market participants ${ }^{84}$.

For South Africa, the prudential carve out was the most important part of the agreement. The delegation was sympathetic of a precise scope, discarding the fourth option like Switzerland, and considering the fifth as the most appropriate. Option two would be acceptable only if "reasonable actions" could be defined in equally precise terms ${ }^{85}$.

Malaysia, speaking for the South East Asian Central Banks (SEACEN) countries: Indonesia, Korea, Nepal, Malaysia, Myanmar, Philippines, Singapore, Sri Lanka and Thailand, stated that as small and developing nations with very open economies, they were vulnerable to external influences, and as such, their stance aimed at protecting the stability of the financial system. They held that liberalization should take into account the characteristics of developing countries' relatively immature financial systems, in light of the system's role in achieving socio-economic development objectives. In short, liberalization should not jeopardize a developing nation's economic and financial stabi$1 i t y{ }^{86}$. In their view, this objective required maximum flexibility for prudential reasons, prioritizing depositor and investor interests.

Furthermore, the SEACEN countries argued that due to the needs of particular countries, and for the measures to be effective with an element of surprise, they should not

86 WTO Doc, MTN.GNS/FIN/3 Note on the Meeting of 13-15 September 1990 (16 October 1990) para.4 [MTN.GNS/ FIN/3]. 
be subjected previous consultations or dispute settlement. Thailand added that it was best for each country to decide the necessity of a measure in a particular situation, an analysis not be questioned through the dispute settlement mechanism ${ }^{87}$. Singapore criticized the second option, considering that due to different philosophies for banking regulation and supervision as well as different standards among countries, the element of reasonableness was very subjective ${ }^{88}$.

The SEACEN position was shared by other developing countries, Mexico agreed that any degree of financial liberalization should provide due account of prudential considerations and the development objectives of developing countries ${ }^{89}$.

As mentioned above, most delegations took the middle-ground, rejecting that the prudential carve-out should establish an unqualified right to regulate, and also rejecting a precise definition that would limit the provision's scope. This position was strongly defended by Canada, Japan, Australia, the United States, the European Communities, and the Nordic countries.

After rejecting the limitation of the prudential carve out to a qualified national treatment provision, the Canadian delegation preferred the second option, and to counteract the possible abuse of such provision, submitted that it should be subjected to dispute settlement ${ }^{90}$. Japan took a very similar position, balancing liberalization and the policy objective of maintaining fair and orderly markets, adding that the prudential carve-out should also be subjected to notification obligations ${ }^{91}$.

Australia considered it fundamental that countries retain sufficient power to manage their financial systems prudentially, and noting the difficulty of negotiating the fifth option, initially sided with options one and two. Since the concept of reasonable would also be difficult to define, there should instead be a broad consensus on the matter ${ }^{92}$.

For the United States, the prudential carve-out was also vital. The scope proposed by the delegation was measures which were "reasonably necessary" for the protection of: the financial service provider, the customer, and the strength and stability of the financial system as a whole. These measures were not to be taken to circumvent the agreement. Furthermore, the prudential carve-out must allow the entrance of new products into markets, due to the increasing innovation in the financial sector ${ }^{93}$.

The fourth option, defended by the SEACEN countries, that promoted an unqualified right of regulation, faced strong responses by the rest of delegations. Switzerland's answer to the SEACEN position recognized that the right to regulate was of central importance, however if understood as broadly, this right could result in a derogation of

91 MTN.GNS/FIN/1 para.80; WTO Doc, MTN.GNS/FIN/2 Note on the Meeting of 12-13 July 1990 (10 August 1990) para. 27 [MTN.GNS/FIN/2].

92 MTN.GNS/FIN/1 para.84.

93 MTN.GNS/FIN/2 para.25. 
the agreement's provisions. In this sense, the right should be qualified to ensure that it could not be abused in a way that would distort trade ${ }^{94}$. This concern was shared by the European Communities, for whom a major concern was ensuring a balance between the right to regulate for prudential reasons, and avoiding the abusive use of said right. The SEACEN proposal could result in de-liberalization by providing an excess of regulatory discretion and a lack of transparency ${ }^{95}$. Canada agreed that some form of recourse should be available to prudential decisions and withdrawing these from the dispute settlement mechanism would create a significant loophole ${ }^{96}$.

Japan added that prudential considerations were not exclusive to developing countries and were important for all nations, although the concept of prudential measures could be different for each country depending on its level of development ${ }^{97}$.

Ultimately, it was the Nordic countries' position that was found to be the most acceptable. The Swedish delegation, speaking on their behalf, considered that the provision should clearly delineate the scope of prudential regulation. Taking a stance against the fourth option that could lead to discriminatory and inappropriate rules, and recognizing the difficulty of having a reasonableness test, Sweden proposed combining the second option with a variation of the third. This would be done by including an illustrative list of legitimate objectives, rather than legitimate measures as initially contemplated. These legitimate objectives could include: the protection of fair and orderly markets, the protection of depositors, investors, insurance policy holders and consumers, and the prevention of inappropriate practices ${ }^{98}$.

TABLE 1. THE MEMBERS' POSITIONS BASED ON THEIR PARTICIPATION AS EVIDENCED IN THE MINUTES

\begin{tabular}{|c|c|c|c|c|}
\hline Option 1 & Option 2 & Option 3 & Option 4 & Option 5 \\
\hline Australia & $\begin{array}{l}\text { Canada } \\
\text { Japan } \\
\text { The European } \\
\text { Communities } \\
\text { India } \\
\text { Australia } \\
\text { Sweden and the Nordic } \\
\text { Countries } \\
\text { USA }\end{array}$ & $\begin{array}{l}\text { Sweden and the } \\
\text { Nordic Countries }\end{array}$ & $\begin{array}{l}\text { Indonesia, } \\
\text { Korea, } \\
\text { Nepal, } \\
\text { Malaysia, } \\
\text { Myanmar, } \\
\text { Philippines, } \\
\text { Singapore, } \\
\text { SriLanka Thailand }\end{array}$ & $\begin{array}{l}\text { Switzerland } \\
\text { South Africa }\end{array}$ \\
\hline
\end{tabular}

In these discussions we can revere the tension between the desire for progressive liberalization, and the importance of protecting a state's right to regulate. As stated by

94 MTN.GNS/FIN/3 para.11.
95 Ibid., para.12.
96 Ibid., para. 15.
97 Ibid., para.22.
98 MTN.GNS/FIN/1 para.85. 
many delegations, negotiating the prudential carve-out provision to finer detail would be exceedingly difficult given the heterogeneous group of Members, the state of their financial systems and economic development, and their banking and regulatory philosophies. We can confirm the abovementioned assertions regarding the prudential carve out, and add to them the following:

- For many Members the prudential carve-out was the most important part of the agreement.

- The Members strongly rejected the application of the prudential carve-out exclusively to National Treatment commitments, and desired to cover all commitments.

- Most Members sought to balance progressive liberalization and a State's right to regulate.

- The final sentence of the prudential carve-out was incorporated to prevent a loophole, and this was also to be achieved by subjecting prudential measures to dispute settlement.

- Members could agree on examples of legitimate objectives that motivate the "prudential reasons", but avoided discussing examples of prudential measures.

- The term "reasonable" was left out of the provision due to the difficulty of defining it.

- Switzerland already disliked a broad prudential carve-out, giving more weight to the predictability and stability sought by financial service suppliers.

These documents give count of the Member States' will in the 1990's during the conformation of the WTO. But perhaps these positions have changed over the years? We will now analyze the present day attitude of the member states towards the prudential cave-out provision.

\section{THE MEMBER STATES' WILL IN DETERMINING THE CONTENT OF THE EXCEPTION IN THE COMMITTEE ON FINANCIAL SERVICES}

In late 2011 Ecuador presented an ambitious proposal for furthering work on regulatory measures in financial services before the Committee on Trade i Financial Services (CFS) ${ }^{99}$. Comparing the dimension of the 2008 financial crisis to that of the Great Depression, Ecuador pointed out that regulatory reforms were being implemented everywhere. As evidence of this, Ecuador cited the G-20 Declaration on Strengthening the Financial System of April 2009, the Group of Thirty Financial Reform: A Framework for Financial Stability of 2009, and the ICMB/CEPR Geneva Reports on the World Economy n. ${ }^{\circ} 11-$ The Fundamental Principles of Financial Regulation of 2009. Through the inclusion of a mandate in the upcoming Ministerial Declaration, Ecuador sought that the Committee in Financial Services review WTO rules, with the purpose of promoting and preserving 
policy space for macro-prudential regulation directed at protecting the stability and integrity of the financial system.

Before the CFS, Ecuador advocated further for the "construction of a new international financial architecture ${ }^{\prime \prime} 100$, seeking that the WTO adapt its rules to the new regulatory reality, as opposed to the old academic and regulatory paradigms of the $1990^{\prime} \mathrm{s}^{101}$. This proposal received immediate support from the representatives of Argentina, Barbados, Bolivia, Brazil, Cuba, the Dominican Republic, India, and South Africa, which considered that the CFS should review relevant rules in financial services due to the recent developments ${ }^{102}$.

To the contrary, the representatives of Chinese Taipei, the EU, Korea, Norway, Australia, and the United States did not approve of including such a paragraph in the upcoming Ministerial Declaration, or the review of existing WTO rules. They maintained that the GATS and the AFS, particularly the prudential carve-out, already provided a high level of discretion for appropriate policy space, and at the same time excluded purely protectionist measures. Canada expressed that the prudential carve-out had functioned adequately providing the member states flexibility in safeguarding their financial systems ${ }^{103}$. However they did welcome further discussion on the financial crisis, particularly the exchange of views and experiences ${ }^{104}$.

As the meeting was the Committee's last for that year, and no consensus was reached, the proposed mandate did not find its way into the ministerial conference declaration. However, the substance of the discussion lived on, as suggested by the representative of Turkey, since the subject matter of the discussion already fell within the Committee's mandate. Turkey also suggested that the Secretariat prepare a Note on the "legal meaning and scope of the prudential carve out, including examples of prudential regulations" ${ }^{\prime \prime}$.

The discussion continued in 2012 with Ecuador's submission of a reviewed and more detailed proposal ${ }^{106}$. Although more concrete and comprehensive, Ecuador's new proposal lacked the edge that had made the previous one so controversial. Ecuador recognized that the desire of preparing a legal interpretation of GATS rules relating to the need for macro-prudential regulation, or identifying specific measures within the scope of WTO provisions was not viable ${ }^{107}$. Many members were concerned that such a discussion could result in narrowing the scope of the existing provisions ${ }^{108}$.

100 WTO Doc, S/FIN/M/71 Report of the Meeting beld on 31 October 2011 (4 November 2011) para.47 [S/FIN/M/71].

$101 \mathrm{~S} / \mathrm{FIN} / \mathrm{M} / 71$ para. 49.

102 Ibid., para. 51.

103 Ibid., para. 54.

104 Ibid., paras. 52,53,55.

105 Ibid., paras. $55,57$.

106 WTO Doc, S/FIN/W/84 Communication from Ecuador "Proposal for discussing progress in respect of macro-prudential regulation and its relationship with GATS rules" (26 June 2012) [S/FIN/W/84].

107 S/FIN/W84 para.14; WTO Doc, S/FIN/M/73 Report of the Meeting beld on 27 June 2012 (30 July 2012) para.8 [S/ FIN/M/73].

108 WTO Doc, S/FIN/M/72 Report of the Meeting beld on 19 March 2012 (31 May 2012) paras. 10,13,14,15,17,20,22; S/FIN/M/73 para. 8 . 
Ecuador's second proposal involves only "dedicated discussion on the steps forward that have been proposed at (an) international level in respect of macro-prudential regulation and its relationship with GATS rules" ${ }^{\prime 109}$. Not quite the construction of the new international financial architecture mentioned earlier. As questions proposed for the discussion and the sharing of views and experiences, Ecuador submitted the following ${ }^{110}$ :

a. What types of new macro-prudential measures have countries identified in recent years and why are they considered necessary in relation to those in existence prior to the recent crisis?

b. How do such measures relate to trade in financial services and the objective of maintaining a solid financial system?

c. Must the WTO cooperate with other international bodies in discussing regulatory needs to ensure consistency with new emerging standards such as the IMF's macro-prudential policy standards?

This proposal received a warmer welcome in the CFS, from both the previous supporters and dissenters. The Turkish delegation that had avidly supported discussing the scope of the prudential carve-out, after acknowledging the concerns of many members, proposed undertaking the discussion suggested by Ecuador on the condition that it be non-binding. In this way, the exchange of views and experiences could be had without raising the concerns that had previously dissuaded many members ${ }^{11}$. Bolivia, Brazil, Cuba, Chile, Argentina, India, and The Republic of Korea, supported Ecuador's proposal without an express reservation ${ }^{112}$.

The approach suggested by Turkey was accepted by many of the critics of Ecuador's first proposal. Although the United States remained cautious, the delegation appreciated that Ecuador was not seeking a legal interpretation of GATS rules relating to macro-prudential regulation, or a list of measures that falls within such scope. The United States characterized such legal interpretation of the prudential carve-out to be "self-defeating in terms of its original objective"113. Likewise, the delegations of South Africa, Egypt, Pakistan, Australia, The Philippines, Switzerland, Mexico, Nigeria, Singapore, The Dominican Republic, Chinese Taipei, and Hong Kong China, supported the proposal, although stating clearly that it should not lead to an interpretation of the prudential carve-out ${ }^{114}$.

With this feedback, Ecuador expressly clarified the parameters of the dedicated discussion to be the following ${ }^{115}$ :

111 WTO Doc, S/FIN/M/74 Report of the Meeting beld on 1 October 2012 (16 November 2012) para. 16 [S/FIN/M/74].

112 S/FIN/M/74 paras. $17,18,19,22,23$.

113 Ibid., para. 21.

114 Ibid., paras. 24,25,27,28,29,32,33,34,35,37,39,40.

115 WTO Doc, S/FIN/M/75 Report of the Meeting beld on 5 December 2012 (21 December 2012) para.8 [S/FIN/M/75]. 
1. It would not lead to an interpretation of GATS rules

2. It would serve to corroborate the flexibility of the current rules on the adoption of prudential regulation

3. It would not seek to identify a list of measures considered as falling within the scope of the GATS framework

4. It would seek to preserve the breadth of the current rules

5. The experiences shared within would only be considered as examples of relevant practices

6. It would not be used to prejudge specific measures taken by the Members

7. It would not seek to prescribe a macro-prudential policy to be necessarily complied with

On these terms, all the delegations accepted the dedicated discussion ${ }^{116}$.

From these documents, we can draw a clear picture on the Members' current attitude towards the prudential cave-out. 24 years later, it remains unchanged for the most part. Although some Members, mainly developing countries, seek a better understanding on prudential regulatory measures, the great majority of Members are zealous on keeping the broad scope of the prudential carve-out, and the flexibility that its wording seemingly provides. Moreover, Members are not interested in questioning the measures taken by others, or identifying specific measures considered as complaint with the GATS regulatory framework. In short, it seems that most WTO Members have no interest in exploring the carve-out's limits, and find refuge in the fog of the provision's ambiguous scope.

It is not clear whether all members are as content with the provision as its most avid advocators like Canada, The United States, and Japan, but ultimately none bring forth their unconformities in the multilateral level. There seem to be few heavyweight nonconformists (Switzerland and the European Union), and they seek to imprint their variations of the prudential carve-out only in bilateral instruments, letting the classic prudential carve out reign free on the multi- and plurilateral levels.

From its genesis, the prudential carve-out's wording was not incidental or pre-fabricated. It is the product of serious negotiations and the confrontation of many wills, wishes, philosophies and standards. The drafting of the provision itself was prudential. Extreme and radical positions were discarded, whether they called out for an unlimited and unquestionable right to regulate, or for the detailed and minute delineation of such right. Dispute settlement would prevent abuse of the provision's broad wording by purely protectionist measures, or any other loophole. We can also note how it was easier to agree on legitimate objectives, rather than specific measures that fall within the provision's scope. In this sense, we can conclude that there is no disagreement on the 
prudential carve-out's finality, the goals and objectives that it should strive for. Yet the means, the measures themselves and the term "prudential", remain consciously ignored.

\section{DISPUTE SETTLEMENT IN THE AFS AS A WINDOW FOR CONSOLIDATING THE TERM} PRUDENTIAL

The prudential carve-out is not the only unique provision in AFS that sets it apart from other WTO disciplines. From the negotiating history of the prudential carve-out we can see how sensitive the matter is, and the importance that the Members gave to dispute settlement as the means to avoid abuse of the provision. For these reasons AFS Paragraph 4 adds a special rule for dispute settlement: "Panels for disputes on prudential issues and other financial matters shall have the necessary expertise relevant to the specific financial service under dispute".

This rule is recognized in Appendix 2 of the DSu relating to "Special or Additional Rules and Procedures Contained in the Covered Agreements". These special rules prevail over the general DSU provisions when there is a conflict between them, but generally fit together with the general rules "to form a comprehensive, integrated dispute settlement system for the WTO Agreement" ${ }^{\prime 17}$. In the Appellate Body's view, "[t]he special or additional provisions listed in Appendix 2 of the DSU are designed to deal with the particularities of dispute settlement relating to obligations arising under a specific covered agreement" ${ }^{\prime \prime 18}$.

AFS Paragraph 4 establishes a key particularity. Article 8 of the DSU already mandates that Panels are to be composed of "well-qualified" individuals, but the AFS goes beyond that, expressly requiring "expertise". Given that the term "expertise" is said of the panels, and not expressly of panelists, some have interpreted that at least one of the panelists must be an expert in finance ${ }^{119}$.

Taking this one step further: what are the implications of the expressly required expertise being present in a panel deciding on a prudential issue? The main consequence is that a strictly lawful interpretation of the prudential carve-out, in accordance with the customary rules of interpretation of treaties, done with the upmost academic rigor, will not be enough. If such method would suffice, there would be no need of AFS paragraph 4 , as the DSU's already well qualified panelists should be well versed in the transversal technique of customary treaty interpretation. DSU paragraph 4 calls for something beyond the analysis of the prudential carve-out undertaken up to this point. It calls for the knowledge of an expert. Consequently, what knowledge would an expert bring into a dispute on prudential issues? We undertake this below, where we contend that through the use of concepts developed in financial law and regulation, the concept of "prudential" could be made less ambiguous by a panel deciding on prudential issues.

117 Guatemala - Anti-Dumping Investigation Regarding Portland Cement from Mexico (Complaint by Mexico) (1998), WTO Doc WT/DS60/AB/R (Appellate Body Report) paras 65-66 [Guatemala-Cement I]; Van den Bossche p. 188.

118 Guatemala - Cement 1 para.66.

119 Bogdandy \& Windsor p. 638 
VII. AN EXAMPLE: LINKING MICRO AND MACRO-PRUDENTIAL POLICY

TO THE PRUDENTIAL CARVE OUT

Prudence is the virtue by which we discern what is proper to do under various circumstances in time and place. John Milton

In this section we aide our interpretation of the prudential carve-out with concepts and knowledge that would form part of the "necessary expertise" that a panel deciding on prudential issues would have. We base our analysis on the premise that the WTO Members by introducing this special rule for dispute settlement, trusted and require, a panel deciding on prudential issues to apply its expertise. In this sense, recourse to the concepts developed below is not arbitrarily based on it being convenient, but rather on the will of the prudential carve-out's creators.

The choice of which concepts of international finance law and regulation are useful in aiding the prudential carve-out's interpretation cannot be arbitrary either. Instead, the choice is determined by the exact wording of the provision. The link with such concepts is achieved through the legitimate objectives which the prudential carve-out signals as examples of prudential reasons. These legitimate objectives have been developed in international finance law and regulation. Around the protection of financial services consumers (investors, depositors, persons to whom a fiduciary duty is owed, etc.) and the integrity and stability of the financial system, we can find concrete regulatory disciplines and concepts.

The author cannot presume to know the extent of such regulatory disciplines and concepts, but will illustrate in a general way that an expert panel could find valuable aide in two concrete disciplines. These are micro-prudential policy and macro-prudential policy, which can bring a more tangible meaning to the idea of prudential regulation.

Recourse to these concepts is not a panacea in face the prudential carve-out's ambiguity as they present identity issues of their own. After the latest financial crisis, "the term 'macroprudential' has become a true buzzword"120, a "fashion statement in financial regulatory circles" ${ }^{\prime 21}$. However it does contain concrete ideas beyond its usage as a fad. When defining it, authors generally contrast the concept with the term "microprudential"122, since the two can be seen complementary like a yin to the yang.

Micro, and macroprudential approaches to regulation distinguish themselves through their objectives and in the risks that concern them. The proximate objective of macroprudential regulation is to limit financial system-wide distress, with the ultimate ob-

120 PIEt Clement, "The Term 'macro-prudential' origins and evolution" (2010) BIS Quarterly Rev. (QL) p. 59 [Clement].

121 HAL S. SCOTT \& ANNA GELPERN, International Finance Law and Regulation (London: Sweet \& Maxwell, 2012) p. $278[$ Scott \& Gelpern].

122 Claudio Borio, "Towards a Macroprudential Framework for Financial Supervision and Regulation?" (2003) BIS Working Paper n. ${ }^{\circ} 128$, p. 2 [Borio]. 
jective of avoiding the "macroeconomic costs linked to financial instability"123. These macroeconomic costs refer to significant losses in the entire economy's real output ${ }^{124}$. On the other hand, microprudential regulation is focused on limiting the distress to individual institutions with the ultimate objective of investor and depositor protection ${ }^{125}$.

As evidenced, microprudential regulation is concerned with the first example of a legitimate objective that the prudential carve-out contains: the protection of certain consumers of financial services, stated by Borio as investors and depositors, something which fits into the traditionally listed creditor consumers. Macroprudential regulation is concerned with the second objective: the integrity and stability of the financial system. Therefore, these two disciplines can provide more tangible criteria on "what is proper to do" when taking a measure to protect these legitimate objectives. They bring more awareness as to the risks and circumstances that put the legitimate objectives in peril, additionally well respected standards can be found that contain principles for avoiding the materialization of such risks.

\section{a. Microprudential policy and the protection of financial services consumers}

As stated above, the ultimate objective of microprudential policy is to protect financial services consumers which are creditors to funds within the system, and it sets out to accomplish that task by limiting the risk to individual institutions. This risk is referred to as "idiosyncratic risk" as opposed to the "systemic risk" which concerns macroprudential policy ${ }^{126}$. In this sense, microprudential policy is concerned with the usage of capital by financial institutions ${ }^{127}$. As mentioned previously, for the purpose of exemplifying the availability of microprudential standards to an expert Panel deciding on a prudential issue, we will focus on the legitimate objective of protecting depositors, which is traditionally listed in prudential carve-out provisions.

Banks transform "short-term deposit funding into long term-loans" ${ }^{228}$. They receive funding form the public's savings, but depositors can promptly withdraw their money. On the other hand, the loans granted usually have a higher maturity and "can be difficult to convert into cash on short notice ${ }^{\prime 129}$. Therefore banks must hold enough liquid resources to handle such withdrawals. This is difficult in situations where depositors

123 Scott \& Gelpern p. 278; Borio p. 2.

124 Borio, p. 2.

125 Ibid

126 IVO MAES, "On the origins of the BIS macro-prudential approach to financial stability" (2009) National Bank of Belgium (Working Paper n. ${ }^{\circ}$ 176) p. 3; Speech by Andrew Crockett, General Manager Bank for International Settlements, Chairman Financial Stability Forum "Marrying the micro- and macroprudential dimensions of financial stability" (21 September 2000) p. 2.

127 ORKIDA ILOLLARI \& GENTIANA GJiNO, "Implementation of macro- and micro-prudential regulation" (2013) 5(1) Rev. of Applied Socio-Econ. Research p. 84.

128 Carmen Reinhart \& Kenneth Rogoff. This Time is Different: Eight Centuries of Financial Folly (Princeton New Jersey: Princeton University Press, 2009) p. 144 [Reinbart \& Rogoff].

129 Ibid., p. XL. 
lose confidence in the safety of their savings and the public massively withdraws ${ }^{130}$. Microprudential policy offers several standards that seek to ensure their confidence and the protection of their savings.

\section{i. The Financial Stability Board: an important standard compiler}

Let us recall that before the CFS, Ecuador pointed at the 2009 G-20 Declaration on Strengthening the Financial System as evidence of increasing concern for financial regulation. Indeed, through this Declaration, the Financial Stability Forum became the Financial Stability Board (FSB), extending participation from the G-10 to include the G-20, and providing the FSB with a stronger mandate ${ }^{131}$. The FSB seeks to "coordinate the work of national financial authorities and international standard setting bodies and to develop and promote the implementation of effective regulatory, supervisory and other financial sector policies"132. And in coordinating international standard setting the FSB has constructed a Compendium of Standards. The FSB's members are central banks and regulators from the G-20 countries as well as the international organizations including the BIS and IMF, and international standard-setting bodies like the BIS' Basel Committee on Banking Supervision (BCBS), the International Association of Insurance Supervisors (IAIS), and the International Organization for Securities Commission (IOSCO). Therefore the compiled standards built from what these members widely accept as good principles, practices, or guidelines ${ }^{133}$.

These Standards are mentioned as examples of applicable expert knowledge, as the purpose of this work is to demonstrate how the prudential carve-out allows for such application. It is not the purpose of this work to argue whether such Standards are necessarily the best knowledge, since compiled best practices with international pretentions are not without criticism ${ }^{134}$.

The FSB recognizes that the implementation of some standards must be prioritized, and refers to these as the key standards ${ }^{135}$. Among them are the Core Principles for Effective Banking Supervision ${ }^{136}$, developed by the BCBS and the Core Principles for Effective Deposit Insurance Systems ${ }^{137}$, developed jointly by the BCBS and the International Association of Deposit Insurers (IADI). The BCBS is committee of the BIS created in 1974 after the co-

130 Ibid., p. 144.

131 Group of Twenty, Press Release, "Global Plan Annex: Declaration on Strengthening the Financial System" (2 April 2009).

132 Financial Stability Board, "About the FSB" online Financial Stability Board (QL).

133 Financial Stability Board, "What are Standards" online Financial Stability Board (QL).

134 James R. Barth, Gerard Caprio Jr. \& Ross Levine, "Banking Regulation and Supervision: What Works Best?" (2001) The World Bank Policy Research (Working Paper n. ${ }^{\circ} 2725$ ) p. 1.

135 Financial Stability Board, "Key Standards for Sound Financial Systems" online Financial Stability Board (QL).

136 Basel Committee on Banking Supervision, "Core Principles for Effective Banking Supervision" September 2012, Bank for International Settlements [CPEBS].

137 Basel Committee on Banking Supervision \& International Association of Deposit Insurers, "Core Principles 
llapse of the German private bank Herstatt, and describes itself as "the primary global standard-setter for the prudential regulation of banks" ${ }^{\prime \prime 38}$. Its members are the central banks of: Argentina, Australia, Belgium, Brazil, Canada, China, France, Germany, Hong Kong SAR, India, Indonesia, Italy, Japan, Korea, Luxembourg, Mexico, The Netherlands, Russia, Saudi Arabia, Singapore, South Africa, Spain, Sweden, Switzerland, Turkey, The United Kingdom, and the United States ${ }^{139}$.

The IADI is also based at the BIS is a forum for deposit insurers around the world, having regional committees in: Africa, Asia-Pacific, the Caribbean, Eurasia, Europe, Latin America, the Middle East and North Africa, and North America ${ }^{140}$. Members are legally instituted deposit insurance systems, currently summing 77 , and participation for international non-profit institutions (like the IMF, World Bank, and Inter-American Development Bank) is available in the form of Partners ${ }^{141}$.

\section{ii. Two examples of useful standards}

The Core Principles for Effective Banking Supervision were originally issued by the BCBS in 1997, having revisions in 2006 and recently in 2012, and "are the de facto minimum standard for sound prudential regulation and supervision of banks ${ }^{\prime \prime 142}$. The currently 29 principles can be broadly classified in two groups, first those that focus on the functions, responsibilities, and powers of supervisors (like Licensing criteria, Major acquisitions, and Corrective and sanctioning powers), and secondly, those that focus on the prudential regulations and requirements for banks (like Credit risk, Capital adequacy, and Disclosure and transparency $)^{143}$. The drafting of the principles, is broad and their neutrality enables different approaches for their implementation "so long as the overriding goals are achieved"144. As mentioned above, to exemplify the availability of microprudential standards to an expert Panel deciding on a prudential issue, we are focusing on the legitimate objective of protecting depositors. A key principle in that regard would be Principle 24 - Liquidity Risk:

for Effective Deposit Insurance Systems" June 2009, Bank for International Settlements \& International Association of Deposit Insurers [CPEDIS].

138 Bank for International Settlements, "About the Basel Committee" online Bank for International Settlements $(\mathrm{QL})$.

139 Bank for International Settlements, "Basel Committee membership" online Bank for International Settlements (QL).

140 International Association of Deposit Insurers, "About IADI" online International Association of Deposit Insurers (QL).

141 International Association of Deposit Insurers, "Members and Participants" online International Association of Deposit Insurers (QL).

142 CPEBS p. 1.

143 Ibid., p. 9.

144 Ibid., p. 13. 
The supervisor sets prudent and appropriate liquidity requirements (which can include either quantitative or qualitative requirements or both) for banks that reflect the liquidity needs of the bank. The supervisor determines that banks have a strategy that enables prudent management of liquidity risk and compliance with liquidity requirements. The strategy takes into account the bank's risk profile as well as market and macroeconomic conditions and includes prudent policies and processes, consistent with the bank's risk appetite, to identify, measure, evaluate, monitor, report and control or mitigate liquidity risk over an appropriate set of time horizons. At least for internationally active banks, liquidity requirements are not lower than the applicable Basel standards ${ }^{145}$.

A measure taken for the prudential reason of protecting depositors would be more likely to be found genuinely prudential if it harmonizes with the objectives of Principle 24: it respects appropriate quantitative or qualitative liquidity requirements; it makes sure that banks have an adequate strategy regarding such requirements that includes the institution's risk profile, market conditions, etc. These principles do not deprive the State of the right to regulate or limit it to a specific measure. Instead they provide a list of objectives that prudential measure should take into account to more effectively protect the "prudential reason". Principles on operational risk (25) credit risk (17) market risks (22), for example, are drafted in the same way as Principle 24. In this way, these standards bring forth a list of elements that an expert panel would consider when determining the reasonability of the measure's "means to ends" connection, as required by the good faith standard discussed above.

The Core Principles for Effective Deposit Insurance Systems are also drafted in a neutral way, "designed to be adaptable to, a broad range of country circumstances, settings and structures" ${ }^{146}$. There are currently 18 Core Principles classified into ten groups: setting objectives, mandates and powers, governance, relationship with other safety-net participants, membership and coverage, funding, public awareness, selected legal issues, failure resolution, and reimbursing depositors and recoveries ${ }^{147}$. Continuing with our exemplification regarding the traditional legitimate objective of depositor protection, these Principles serve to elucidate further elements that prudential measures should strive for, since they are geared to making deposit insurance stronger. For example, one of these is the purpose in Principle 2 - Mitigating Moral Hazard:

Moral hazard should be mitigated by ensuring that the deposit insurance system contains appropriate design features and through other elements of the financial system safety net ${ }^{148}$. 
The principle does not mandate exactly how a State should mitigate moral hazard; the Preconditions broadly suggest good corporate governance and the adequate risk management of individual banks ${ }^{149}$. However this mitigation is an objective that regulators must keep in mind. Consequently, GATS inconsistent measures taken by a State claiming "prudential reasons" in this area would be less likely to be found genuinely prudential by an expert Panel if they completely disregard the objective of mitigating moral hazard.

Other principles may leave less ground for discretion, for example Principle 8 regarding compulsory membership states:

Membership in the deposit insurance system should be compulsory for all financial institutions accepting deposits from those deemed most in need of protection (eg retail and small business depositors) to avoid adverse selection ${ }^{150}$.

In this sense, a measure that imposes membership in the deposit insurance system to a foreign institution because it accepts deposits from small businesses, but not extend the same requirement to domestic institutions that also accept deposits from small businesses, would probably not prudential. In light of this principle, different treatment regarding compulsory membership in the deposit insurance system could only be rationally based on the nature of the financial institutions' consumers.

Some of the recent principle compendiums not yet categorized as "key", include the FSB's Principles for an Effective Risk Appetite Framework of November 2013 ${ }^{[151]}$, and the IOSCO's Principles for Financial Benchmarks of July $2013^{[152]}$. The total list under Financial Regulation and Supervisions sums more than 150, and as we can see the FSB's Compendium is under constant growth and revision.

\section{iii. Moving towards integrating a macroprudential outlook}

Before the crisis, many thought that the minimum requirements set for banking institutions were enough to keep the financial system was safe but this traditional position has received heavy criticism: "the current approach has been found wanting. It implicitly assumes that we can make the system as a whole safe by simply trying to make sure that individual banks are safe"153. This has been called a fallacy of composition ${ }^{154}$.

149 Ibid., pp. 8-9.

150 Ibid., p. 3.

151 Financial Stability Board, "Principles for an Effective Risk Appetite Framework" (November 2013) (QL).

152 Board of the International Organization of Securities Commission, "Principles for Financial Benchmarks" (July 2013) (QL); IOSCO principles would be helpful to a Panel resolving a prudential matter concerned with the protection of investors and fair and orderly markets, which were also of great concern as evidenced in the negotiating history MTN/GNS/FIN/1 para.85.

153 Markus BrunNermeier et al. "The Fundamental Principles of Financial Market Regulation" (2009) Geneva Reports on the World Economy 11 (International Centre for Monetary and Banking Studies \& Centre for Economic Policy Research) pp. vx, 15.

154 International Monetary Fund: Monetary and Capital Markets Department "Macroprudential Policy: 
A fallacy of composition consists in erroneously attributing a property of the constituent parts to the whole ${ }^{155}$. In this context, the soundness of individual institutions does not guarantee the stability of the system as a whole. Furthermore, it has been recognized that "actions that are appropriate for individual firms may collectively lead to, or exacerbate, system-wide problems ${ }^{\prime 156}$. In light these circumstances, additionally to strengthening microprudentail policy, standard setting bodies like the BCBS seek to include a macroprudential focus "addressing system wide risks that can build up across the banking sector" ${ }^{\prime 157}$. Consequently, in determining whether a measure taken by a State for prudential reasons is genuinely prudential, an expert panel could also find aide the concepts developed by macroprudential policy.

\section{b. Macroprudential Policy and the stability of the financial system}

A measure adopted by a State for the prudential reason of protecting the stability of the financial system would be more likely to be considered as prudential if it could be categorized as falling within macroprudential policy. We will present the general aspects of macroprudential policy and the enemy that it faces when protecting the financial system.

\section{i. Defining the concept of macroprudential policy}

As previously warned, the term "macroprudential" has identity issues of its own. The IMF recognizes that there is no commonly accepted definition of macroprudential policy, its objectives, and instruments, given that the discussion and development of the concept if far from being settled in academic and regulatory circles ${ }^{158}$. However, the underlying idea has remained constant and serves as a direct link to the second legitimate objective exemplified in the prudential carve-out: the integrity and stability of the financial system.

In 2010, Piet Clement thoroughly analyzed the origin and evolution of the term macroprudential. After originating in the 1970's "the term has always denoted concerns over the financial system's stability and its link with the macroeconomy" ${ }^{\prime 159}$. The focus of the concerns has varied, ranging from "excessive lending to developing countries" to "the impact of financial innovation and the development of capital markets" ${ }^{\prime 60}$. The

An Organizing Framework" (14 March 2011) p. 9 [IMF-Organizing Framework]; STEPHEN MORRIS \& HYUN SHIN, "Financial Regulation in a Systemic Context" (2008) Brookings Papers on Economic Activity 229, p. 272.

155 Hans Hansen \& Robert Pinto, Fallacies: Classical and Contemporary Readings (Pennsylvania: Penn State Press, 1995) p. 141.

156 IMF-Organizing Framework p. 9.

157 Basel Committee on Banking Supervision, "Strengthening the resilience of the banking sector" (2009)

Consultative Document p. 2 [BCBS-Strengthening].

158 IMF-Organizing Framework p. 7.

159 Clement p. 65.

160 Ibid. 
latest concern has been "the failure of systematically significant institutions"161. Clement notes that defining macroprudential through contrast with what he calls its "antonym" microprudential, the concept is clearer and closer to its origin.

We have previously referred to this as the "yin-yang" approach, and prefer this terminology since it does not pitch the two terms as antagonists but rather as complementary. For Clement, achieving this balance is the main challenge and objective of the international community ${ }^{162}$. For example, the subject of the BIS annual meeting in October of 2000 was "marrying the micro- and macro-prudential dimensions of financial stability"163. A more recent example is the approach taken by the BCBS through the package of fundamental reforms dubbed Basel III, based on the reasoning that "[c]learly these two micro and macroprudential approaches to supervision are interrelated, as greater resilience at the individual bank level reduces the risk of system wide shocks"164.

Following the yin-yang approach, Clement finds macroprudential as referring to: "the use of prudential tools with the explicit objective of promoting the stability of the financial system as a whole, not necessarily of the individual institutions within it"165. Similarly, for the IMF macroprudential policy aims at maintaining financial stability through the use of "prudential tools to limit systemic or system-wide financial risk" ${ }^{166}$. In this way, we can see macroprudential policy as the medicine that aims at keeping the financial system immune from systemic risk, to ultimately avoid harm to the macro-economy.

\section{ii. The Virus of Systemic Risk}

As macroprudential regulation strives for the stability of the system as a whole ${ }^{167}$, a "central element" in its definition is the notion of "systemic risk"168. In 2001 the working definition for the Group of Ten (Belguim, Canada, France, Germany, Italy, Japan, Netherlands, Sweden, Switzerland, United Kingdom, United States) was: "the risk that an event will trigger a loss of economic value or confidence in, and attendant increases in uncertainly about, a substantial portion of the financial system that is serious enough to quite probably have significant adverse effects on the real economy" ${ }^{\prime 169}$. It also pointed out that systemic risk events could be unexpected, as well as of growing likeliness due to inappropriate policy responses, and that the adverse real economic effects would

161 Ibid.

162 Ibid., p. 65.

163 BIS Monetary and Economic Department "BIS Papers n. ${ }^{\circ} 1$ : Marrying the macro- and microprudential dimensions of financial stability" (2001) Bank for International Settlements (QL).

164 BCBS-Strengthening p. 2.

165 Clement p. 65.

166 IMF-Organizing Framework p. 7.

167 AvinASH PERSAUd, "Macro-Prudential Regulation: Fixing Fundamental Market (and Regulatory) Failures" (2009) World Bank Group Crisis Response (Note n. ${ }^{\circ}$ 6), p. 2.

168 IMF-Organizing Framework p. 7.

169 Group of Ten, "Report on Consolidation in the Financial Sector" (2001) p. 126. 
generally be triggered by disruptions in the systems of payment and credit flows as well as through the decay of asset values ${ }^{170}$.

The G10 points at two underlying assumptions in its definition: a) "economic shocks may become systemic because of the existence of negative externalities associated with severe disruptions in the financial system", and b) "systemic financial events must be very likely to induce undesirable real effects, such as substantial reductions in output and employment, in the absence of appropriate policy responses" ${ }^{\prime 171}$.

Based on this definition, the European Parliament Policy Department draws three characteristics of systemic risk: a) it is a risk to the financial system as a whole, b) it "involves spillovers of risk from one institution to many others", and c) materialization of systemic risk is usually linked to "adverse macro economy effects in the absence of rapid and strong policy responses" ${ }^{\prime 172}$.

The G10 formulation of systemic risk lived through the crisis and in their 2009 report to the G20 the IMF, BIS, and FSB similarly define systemic risk as "a risk of disruption to financial services that is (i) caused by an impairment of all or parts of the financial system and (ii) has the potential to have serious negative consequences for the real economy"173. Keeping up with the metaphor, systemic risk would be the virus that after infecting and disrupting one, or a few financial institutions, spreads throughout the system and results in significantly deteriorated macroeconomic health.

Hals Scott breaks down the concept into what he calls the "three Cs of systemic risk" which refer to three problems: correlation, connectedness, and contagion ${ }^{174}$. These are the ways through which shocks, or negative externalities, spread through the financial system and ultimately into the real economy ${ }^{175}$. There is a problem of correlation when several financial institutions are stakeholders to the same risk and will be simultaneously impacted if such risk materializes. They are exposed to the same negative events by having investments in the same sector, for example the Us housing market prior to $2007^{[176]}$. There is a problem of connectedness when the failure of one institution causes the collapse of its contractual counterparties as would be the case of a "chain reaction of bank failures"177. Essentially when one goes down and others follow due to legal and economic ties.

170 Ibid

171 Ibid.

172 Stephan Gerlach, "Defining and Measuring Systemic Risk" (23 November 2009) European Policy Dep. (QL) p. 3 .

173 International Monetary Fund, Bank for International Settlements \& Financial Stability Forum, "Guidance to Assess the Systemic Importance of Financial Institutions, Markets and Instruments: Initial Considerations" (20 October 2009) Report to the G-20, pp. 5-6.

174 Hal S. SCOTT "How to Improve Five Important Areas of Financial Regulation" in Rules for Growtb: Promoting Innovation and Growth Through Legal Reform (Yale Law and Economics Research Paper n. ${ }^{\circ} 426,2011$ ) 113 , p. 114 [Scott].

175 Miguel Dijkman, "A Framework for Assessing Systemic Risk" (2010) The World Bank (Policy Research Working Paper n. ${ }^{\circ}$ 5283) (QL) p. 6 [Dijkman].

176 Scott \& Gelpern p. 21

177 Scott p. 114; Scott \& Gelpern p. 22 
The problem of contagion ${ }^{178}$ is a "broader and more elusive"179. It consists of behavioral changes by economic agents when responding to a particular event ${ }^{180}$. The traditional example is a bank run where depositors scramble to retrieve their deposits because they assume their bank will fail ${ }^{181}$. Contagion can be rational, a reaction to real deficiencies, and also irrational when insufficient or wrong information herds a flight to safety or liquidity ${ }^{182}$.

\section{iii. Exemplifying a useful macroprudential standard}

Given that a determined focus on macroprudential policy is recent, the approaches, principles and standards are still debated ${ }^{183}$. However the FSB's Compendium does contain guidelines in certain areas, for example the Guidance on Identification of Critical Functions and Critical Shared Services ${ }^{184}$. These guidelines seek to provide evaluation criteria to assist in determining what functions and services provided by a bank are critical for the real economy, meaning that their discontinuity could result in the systematically adverse consequences discussed above.

Instead of taking a State's word that a measure was taken to safeguard a critical function and ensure the stability of the financial system, an expert panel could make use of the steps that the FSB guidelines put forth. These involve a much more serious and thorough analysis to determine whether the measure does in fact meet a reasonable means to ends approach. Step one would be to "assess the impact of failure" where the FSB puts forth a copious amount of factors to take into consideration such as: the nature and extent of this activity (global, domestic, concerning payments, etc.), the nature of the customers and stakeholders (corporate, retail, involving housing, etc.), how fast the impact of the disruption will be, will consumers have time to react, interdependencies between markets, whether the products are tied to others, to name a few ${ }^{185}$. Step two would be to "evaluate the market for the function", taking into account: if the market can quickly substitute the service provider, if there is a high level of market concentration,

178 Some refer to correlation and connectedness as contagion through the real channel, see Dijkman p. 6 ; MATT PriTZKER, "The Channels for Financial Contagion" (2000) The World Bank, p. 3 (QL); Scott reserves the name only for contagion through the information/social channel.

179 Scott \& Gelpern p. 23.

180 Dijkman, p. 6.

181 Douglas Diamond \& Phillip Dybvig, "Bank Runs, Deposit Insurance, and Liquidity" (1983) 91(3) Jrnl. of Pol. Econ. 401, p. 401

182 Scott \& Gelpern p. 23; see also Lieven Baele et al. "Flights to Safety" (2013) National Bureau of Economic Research (Working Paper n. ${ }^{\circ}$ 19095).

183 For example: Bogdan Glavan \& Flava AnGHEL, "We are Not Macroprudentialists: A Skeptical View of Prudential Regulation to Deal with Systemic Externalities" (2013) 17(3) The Independent Rev. 349.

184 Financial Stability Board, "Recovery and Resolution Planning for Systematically Important Financial Institutions: Guidance on Identification of Critical Functions and Critical Shared Services" (16 July 2013) (QL) [FSB-Guidance on Id. Critical Functions \& Services].

185 FSB-Guidance on Id. Critical Functions \& Services pp. 8-9. 
the percentage of market share, how do the institutions compete, would other providers want to assume the activities, and the list goes on and on ${ }^{186}$. Step three would carry out the analysis on a firm by firm basis ${ }^{187}$.

As we can see, the determination of whether a measure is genuinely taken for a prudential reason can be severely technical, a drastic change from simply accepting a WTO Member's statement. It is an analysis that would surpass the capabilities of a "well qualified" WTO panel. Yet it is not an analysis that would be out of reach to the expert panel that the AFS requires. Part of the knowledge an expert panel could employ are micro- and macroprudential policy concepts given that these disciplines are in their very definition linked to the legitimate objectives the prudential cave-out lists as "prudential reasons".

\section{CONCLUSION: THE PRUDENTIAL CARVE-OUT CAN BE DEMYSTIFIED BY THE EXPERT PANEL THE AFS DEMANDS}

The objective undertaken in this work was to limit the ambiguity of the prudential carve-out provision to the greatest extent, in a way that respects DSU Article 3.2. This means that the interpretation cannot add to, or diminish, the content of the prudential carve-out, and the rights and obligations of WTO Members. Through the analysis that an ordinary Panel would take, following the customary rules of treaty interpretation, the ambiguity that surrounds the prudential carve-out can be limited to some extent:

- The prudential reasons that inspire the taking of measures covered by the carveout are considered important enough to merit creating a safeguard clause specifically for financial services, unlike any other in the WTO context. This is linked to the fact that for many Members the prudential carve out was the most important provision in the Agreement.

- The prudential reasons enable the measures covered by the carve-out to ignore or not comply with acquired commitments despite all other provisions in the treaty, having the Members rejected limiting its scope to specific commitments like National Treatment.

- The prudential reasons are not listed exhaustively and include the protection of certain financial consumers (it sets the traditional approach to list consumers that are creditors to funds), and the integrity and stability of the financial system as a whole. This is due to the fact that members could agree on examples of legitimate objectives that motivate the "prudential reasons", but avoided discussing examples of prudential measures themselves.

- The prudential carve-out is does not contain elements that configure the chapeau of other WTO exceptions like the terms "necessary" and "not more burdensome than necessary". 
- The final sentence of the prudential carve-out was incorporated to prevent a loophole. The concept of abus de droit is present in this final sentence meaning measures undertaken cannot be used to avoid GATS commitments, and must remain genuinely linked to the prudential reasons through a reasonable means to ends connection, even though the term "reasonable" was left out due the difficulty of defining it.

- The concept of "prudential" is linked to an idea of thinking/acting ahead to avoid certain harmful circumstances.

- The prudential carve-out provision reflects two GaTS objectives/principles, progressive liberalization and the right to regulate, and the desire to find balance between them. Most Members sought to balance these two objectives.

- The prudential carve-out is not the only peculiar provision in the AFS and must be interpreted in connection with Paragraph 4 which mandates that a panel deciding on prudential issues have the "necessary expertise".

These conclusions that can be reached through the customary rules of treaty interpretation still leave a degree of uncertainty as to the prudential carve-out's scope of application. However this interpretation reveals the key, on exactly how this scope is to be determined. The importance given to dispute settlement by the WTO Members as the means to safeguard the principle of progressive liberalization and prevent a loophole open to abuse is materialized in Paragraph 4 of the AFS. This particular form of dispute settlement is the window that enables the demystification of the prudential carve-out. Without it, if prudential matters would be subjected to resolution by ordinary Panels, the greatest degree of clarity to be reached would be the previously stated conclusions.

However, being subjected to a qualified form of dispute settlement, the prudential carve-out demands "expertise". The correct application of such expertise would not be inconsistent with DSU Article 3.2, and on the contrary, follows the will of WTO Members. Through the application of its knowledge, an expert panel deciding on a prudential issue has the necessary elements to determine the measure's reasonable means to ends connection with the prudential reason, in short, to determine if it is genuine.

To exemplify what knowledge an expert panel could apply, we have touched on the concepts developed in both microprudential and macroprudential policy due to their tangible link with the legitimate objectives the prudential carve-out illustrates as prudential reasons. The examples have centered on depositor protection and the banking sector. However, nothing prevents the same being done with other legitimate objectives (such as investors and securities market efficiency, since that would also call for expert knowledge). These disciplines provide well respected global standards in certain areas, which bring into perspective particular elements that measure must take into account to be effective when protecting financial services consumers of a particular nature, or the financial system as a whole.

Through the analysis presented, the scope of application of the GATS AFS prudential carve-out can be clarified to an acceptable degree, relying on a Panel's expert knowledge in accordance with the WTO Member's mandate. This is done in a way that does not add 
to, or diminish, the rights and obligations of WTO Members. The application of expert knowledge cannot be capricious, instead maintaining a strict relationship with the legitimate objectives contained in the provision, which is tangible manifestation of the WTO Members' will. Such expert knowledge serves to determine if a particular measure maintains a reasonable means to ends connection with the prudential carve-out's legitimate objectives. Consequently, if a WTO Panel ever faces a controversy on prudential matters, the prudential carve-out can be demystified following this analysis.

BIBLIOGRAPHY

Treaties

WTO Covered Agreements

WTO Agreements under the Marrakesh Agreement Establishing the World Trade Organization, 1867 U.N.T.S. 154 (1994)

Agreement on the Application of Sanitary and Phytosanitary Measures, 1867 U.N.T.S. 493

Cited as: sps

Agreement on Technical Barriers to Trade, 1868 U.N.T.S. 120

Cited as: TBT

General Agreement on Trade in Services (GATS), 1869 U.N.T.S. 183

Cited as: GATS

Understanding on Rules and Procedures Governing the Settlement of Disputes, 1869 U.N.T.S. 401

Cited as: DSU

\section{Free Trade Agreements}

Trade Promotion Agreement between Canada and Colombia, 21 November 2008 (entered into force 15 August 2011)

Cited as: Canada-Colombia FTA

Free Trade Agreement between Canada and the Republic of Honduras, 5 November 2013 (entered into force 1 October 2014)

Cited as: Canada -Honduras FTA

Free Trade Agreement between Canada and the Republic of Korea, 22 September 2015 (entered into force 1 January 2015)

Cited as: Canada-Korea FTA

Acuerdo de Libre Comercio entre la República de Colombia y la República de Costa Rica, 22 May 2013 (not yet in force)

Cited as: Costa Rica-Colombia FTA

Free Trade Agreement between the EFTA States and the Central American States, June 242013 (for EFTA, Costa Rica, and Panama) (entered into force 19 August 2014 for Costa Rica, Panama and Norway; 29 August 2014 for Liechtenstein and Switzerland; 5 September 2014 for Iceland) 
Cited as: EFTA-Central America FTA

Free Trade Agreement between the Republic of Colombia and the EFTA States, 25

November 2008 (entered into force 1 July 2011 for Colombia, Lichtenstein, and Switzerland; 1

September 2014 for Norway; 1 October 2014 for Iceland)

Cited as: EFTA-Colombia FTA

Free Trade Agreement between the EFTA States and the Republic of Korea, 15 December 2005

(entered into force 1 September 2006 for Norway, Liechtenstein and Switzerland, 1 October 2006 for Iceland)

Cited as: EFTA- Korea FTA

Free Trade Agreement between the EFTA States and Mexico, 27 November 2000 (entered into force 1 July 2001)

Cited as: EFTA-Mexico FTA

Free Trade Agreement between the EFTA States and Singapore, 26 June 2002 (entered into force 1 January 2003)

Cited as: EFTA-Singapore FTA

Trade Agreement between The European Union and its Member States, of the one part, and

Colombia and Peru, of the other part, 26 June 2012 (entered into force 1 August 2013)

Cited as: EU-Colombia FTA

Free Trade Agreement between the European Union and the Republic of Korea, 15 October 2009 (entered into force 1 July 2011)

Cited as: EU-Korea FTA

Free Trade Agreement between the European Union and Singapore, Negotiations Concluded 17

December 2012 (not yet in force)

Cited as: EU-Singapore FTA

Agreement between Japan and Australia for an Economic Partnership, 8 July 2014 (entered into force 15 January 2015)

Cited as: Japan-Australia EPA

Agreement between Japan and Mongolia for an Economic Partnership, 10 February 2015 (not yet in force)

Cited as: Japan-Mongolia EPA

Agreement between Japan and the Republic of Peru for an Economic Partnership, 31 May 2011

(entered into force 1 March 2012)

Cited as: Japan-Peru EPA

Agreement on Free Trade and Economic Partnership between Japan and the Swiss Confederation,

19 Februrary 2009 (entered into force 1 September 2009)

Cited as: Japan-Switzerland FTA

Tratado de Libre Comercio entre los Estados Unidos Mexicanos y la República de Colombia, 13 June 1994 (entered into force 1 January 1995)

Cited as: Mexico-Colombia FTA

North American Free Trade Agreement, 17 December 1992 (entered into force 1 January 1994)

Cited as: NAFTA 
Acuerdo de Libre Comercio entre la República de Colombia y la República de Panamá, 20 September 2013 (not yet in force)

Cited as: Panama-Colombia FTA

Trade Promotion Agreement between the United States of America and the Republic of Colombia, 22 November 2006, (entered into force 15 May 2012)

Cited as: US-Colombia FTA

Free Trade Agreement between the United States of America and the Republic of Korea, 30 June 2007 (entered into force 15 March 2012)

Cited as: US- Korea FTA

Trade Promotion Agreement between the United States of America and the Republic of Panama, 28 June 2007, (entered into force 31 October 2012)

Cited as: Us-Panama FTA

Other

Vienna Convention on the Law of Treaties, 23 May 1969, 1155 UNTS 331; 8 ILM 679

\section{Statutes}

Ley 19.496 (Chile) 1997

Ley 20.555 (Chile) 2011

Ley 1328 (Colombia) 2009

Ley Federal de Protección al Consumidor (Mexico) 1992

Ley de Protección y Defensa al Usuario de Servicios Financieros (Mexico) 1999

Ley 29.571 Código de Protección y Defensa al Consumidor (Peru) 2010

Dodd-Frank Wall Street Reform and Consumer Protection Act, Pub. L. n. ${ }^{\circ} 111-203$, (US) 2010

\section{Official WTO Documents}

\section{Committee on Trade in Financial Services Minutes}

WTO Doc, S/FIN/M/71 Report of the Meeting beld on 31 October 2011 (4 November 2011)

WTO Doc, S/FIN/M/72 Report of the Meeting beld on 19 March 2012 (31 May 2012)

WTO Doc, S/FIN/M/73 Report of the Meeting beld on 27 June 2012 (30 July 2012)

WTO Doc, S/FIN/M/74 Report of the Meeting beld on 1 October 2012 (16 November 2012)

WTO Doc, S/FIN/M/75 Report of the Meeting beld on 5 December 2012 (21 December 2012)

\section{Committee on Trade in Financial Services Working Documents}

WTO Doc, S/FIN/W/73 Background Note by the Secretariat (3 February 2010)

WTO Doc, S/FIN/W/80 Communication from Ecuador "Proposal for furthering work on Regulatory Measures in Financial Services for inclusion in the Ministerial Declaration" (7 October 2011) 
WTO Doc, S/FIN/W/84 Communication from Ecuador "Proposal for discussing progress in respect of macro-prudential regulation and its relationship with GATS rules" (26 June 2012)

\section{Multilateral Trade Negotiations in Financial Services}

WTO Doc, MTN.GNS/FIN/1 Note on the Meeting of 11-13 June 1990 (5 July 1990)

WTO Doc, MTN.GNS/FIN/2 Note on the Meeting of 12-13 July 1990 (10 August 1990)

WTO Doc, MTN.GNS/FIN/3 Note on the Meeting of 13-15 September 1990 (16 October 1990)

WTO Doc, MTN.GNS/FIN/4 Note on the Meeting of 19-20 October 1990 (30 November 1990)

\section{Cases}

\section{International Court of Justice}

Ambatielos Case (Greece v United Kingdom) Preliminary Objection, [1952] ICJ Rep 28

Asylum Case (Colombia v Peru) Judgment of 20 November 1950 [1950] ICJ Rep 266

Case Concerning Kasikili/Sedudu Island (Botswana v Namibia) Judgment of 13 December 1999 [1999] ICJ Rep 1045

Case Concerning Rights of Nationals of The United States of America in Morocco (France v United States) Judgment of August 27 1952, [1952] ICJ Rep 176

Case Concerning the Arbitral Award of 31 July 1989 (Guinea-Bissau v Senegal) Judgment of 12

November 1991 Dissenting Opinion of Judge Weeramantry [1991] ICJ Rep 130

Case of Certain Norwegian Loans (France v Norway) Judgment of 6 July 1957 Separate Opinion of Judge Sir Hersch Lauterpacht [1957] ICJ Rep 34

Corfu Channel Case (United Kingdom v Albania) Judgment of 9 April 1949 [1949] ICJ Rep 2

Oil Platforms Case (Islamic Republic of Iran v United States) Judgment of 6 November 2003 [2003] ICJ Rep 161

Territorial Dispute Case (Libyan Arab Jamahiririya v Chad) Judgment of 3 February 1994 [1994] ICJ Rep 4

\section{Permanent Court of Arbitration}

Case Concerning the Beagle Channel (Argentina v Chile) "Award of the Tribunal" (18 February 1971) 57

Russian Claim for Interest on Indemnities (Russia v Turkey) "Award of the Tribunal" (11 November 1912) (Unofficial English Translation) The Hague, p. 3

\section{Permanent Court of International Justice}

Competence of the ILO in regard to International Regulation of the Conditions of the Labour of Persons Employed in Agriculture "Advisory Opinion" (12 August 1922) PCI Series B n. ${ }^{\circ}$ 2, 9 Legal Status for Eastern Greenland "Judgment" (5 April 1933) PCI Series A/B n. ${ }^{\circ}$ 53, 22 
Polish Postal Service in Dazing "Advisory Opinion" (16 May 1925) PCIJ Series B n. ${ }^{\circ} 11,4$

\section{WTO Appellate Body}

Argentina - Measures Affecting Imports of Footwear, Textiles, Apparel and other Items (Complaint by United States) (1998) WTO Doc WT/DS56/AB/R (Appellate Body Report)

Argentina - Safeguard Measures on Imports of Footwear (Complaint by European Communities) (1999) WTO

Doc WT/DS121/AB/R (Appellate Body Report)

Australia - Measures Affecting Importation of Salmon (Complaint by Canada) (1998) WTO Doc WT/DS18/ $\mathrm{AB} / \mathrm{R}$ (Appellate Body Report)

Brazil - Measures Affecting Imports of Retreaded Tyres (Complaint by European Communities) (2007) WTO Doc WT/DS332/AB/R (Appellate Body Report)

Canada - Certain Measures Affecting the Automotive Industry (Complaint by Japan) (2000) WTO Doc WT/ DS139/AB/R (Appellate Body Report)

Canada — Certain Measures Concerning Periodicals (Complaint by United States) (1997) WTO Doc WT/DS31/ $\mathrm{AB} / \mathrm{R}$ (Appellate Body Report)

Canada - Measures Affecting the Export of Civilian Aircraft (Complaint by Brazil) (1999) WTO Doc WT/ $\mathrm{DS70/AB} / \mathrm{R}$ (Appellate Body Report)

Canada - Measures Affecting the Importation of Milk and the Exportation of Dairy Products (Complaint by United States) (1999) WTO Doc WT/DS103/AB/R (Appellate Body Report)

China - Measures Affecting Trading Rights and Distribution Services for Certain Publications and Audiovisual

Entertainment Products (Complaint by United States) (2009) WTO Doc WT/DS363/AB/R (Appellate Body Report)

European Communities - Regime for the Importation, Sale and Distribution of Bananas (Complaint by Ecuador, Honduras, Guatemala, Mexico, United States) (1997) WTO Doc WT/DS27/AB/R (Appellate Body Report)

European Communities - Customs Classification of Certain Computer Equipment (Complaint by United States)

(1998) WTO Doc WT/DS62/AB/R (Appellate Body Report)

European Communities - Customs Classification of Frozen Boneless Chicken Cuts (Complaint by Brazil) (2005) WTO Doc WT/DS269/AB/R (Appellate Body Report)

European Communities - Measures Affecting Asbestos and Products Containing Asbestos (Complaint by Canada) (2001) WTO Doc WT/DS135/AB/R (Appellate Body Report)

European Communities - Selected Customs Matters (Complaint by United States) (2006) WTO Doc WT/DS315/ AB/R (Appellate Body Report)

Guatemala - Anti-Dumping Investigation Regarding Portland Cement from Mexico (Complaint by Mexico) (1998), WTO Doc WT/DS60/AB/R (Appellate Body Report)

India - Patent Protection for Pharmacentical and Agricultural Chemical Products (Complaint by United States) (1997) WTO Doc WT/DS50/AB/R (Appellate Body Report)

India - Quantitative Restrictions on Imports of Agricultural, Textile and Industrial Products (Complaint by United States) (1999) WTO Doc WT/DS9o/AB/R (Appellate Body Report)

Japan - Taxes on Alcobolic Beverages (Complaint European Communities) (1996) WTO Doc WT/DS8/AB/R

(Appellate Body Report) 
Japan — Measures Affecting Agricultural Products (Complaint by United States) (1999) WTO Doc WT/DS76/ $\mathrm{AB} / \mathrm{R}$ (Appellate Body Report)

Korea - Definitive Safeguard Measure on Imports of Certain Dairy Products (Complaint by European Communities) (1999) WTO Doc WT/DS98/AB/R (Appellate Body Report)

Korea - Measures Affecting Imports of Fresh, Chilled and Frozen Beef (Complaint by United States) (2000) WTO Doc WT/DS161/AB/R (Appellate Body Report)

United States - Anti-Dumping Measures on Certain Hot-Rolled Steel Products from Japan (Complaint by Japan) (2001) WTO Doc WT/DS184/AB/R (Appellate Body Report)

United States - Countervailing Duties on Certain Corrosion-Resistant Carbon Steel Flat Products from Germany (Complaint by European Communities) (2002) WTO Doc WT/DS213/AB/R (Appellate Body Report)

United States —Definitive Safeguard Measures on Imports of Circular Welded Carbon Quality Line Pipe from Korea (Complaint by Korea) (2002) WTO Doc WT/DS202/AB/R (Appellate Body Report)

United States - Final Countervailing Duty Determination with respect to certain Softwood Lumber from Canada (Complaint by Canada) (2004) WTO Doc WT/DS257/AB/R (Appellate Body Report)

United States - Import Probibition of Certain Sbrimp and Sbrimp Products (Complaint by India, Malaysia, Pakistan, Thailand) (1998) WTO Doc WT/DS58/AB/R (Appellate Body Report)

United States - Measures Affecting the Cross-Border Supply of Gambling and Betting Services (Complaint by Antigua y Barbuda) (2005) WTO Doc WT/DS285/AB/R (Appellate Body Report)

United States - Measures Concerning the Importation, Marketing and Sale of Tuna and Tuna Products (Complaint by Mexico) (2012) WTO Doc WT/DS381/AB/R (Appellate Body Report)

United States - Standards for Reformulated and Conventional Gasoline (Complaint by Bolivarian Republic of Venezuela) (1996) WTO Doc WT/DS2/AB/R (Appellate Body Report)

United States - Subsidies on Upland Cotton (Complaint by Brazil) (2005) WTO Doc WT/DS267/AB/R (Appellate Body Report)

United States - Sunset Review of Anti-Dumping Duties on Corrosion-Resistant Carbon Steel Flat Products from Japan (Complaint by Japan) (2003) WTO Doc WT/DS244/AB/R (Appellate Body Report)

\section{WTO Panel Reports}

China - Certain Measures Affecting Electronic Payment Services (Complaint by United States) (2009) WTO Doc WT/DS413/R (Panel Report)

China - Measures Affecting the Protection and Enforcement of Intellectual Property Rights (Complaint by United States) (2009) WTO Doc WT/DS362/R (Panel Report)

United States - Sections 301-310 of the Trade Act 1974 (Complaint by European Communities) (1999) WTO Doc WT/DS152/R (Panel Report)

\section{Books}

Bogdandy, Armin von. \& Windsor, Joseph. "Annex on Financial Services" in RuideGer Wolfrum, Peter-Tobais Stoll, \& Clemens Feinaugle, eds., Max Planck Commentaries on World Trade Law: WTO Trade in Services (Leiden- Boston: Martinus Nijhoff Publishers, 2008) 618

Brownle, Ian. Principles of Public International Law (New York: Oxford University Press, 2008) 
Evans, Malcom D. International Law (New York: Oxford University Press, 2010)

Hansen, Hans \& Pinto, Robert. Fallacies: Classical and Contemporary Readings (Pennsylvania: Penn State Press, 1995)

Hestermeyer, Holeger. "Preamble gats" in Ruideger Wolfrum, Peter-Tobais Stoll, \& Clemens FeInAUGle, eds., Max Planck Commentaries on World Trade Law: WTO Trade in Services (Leiden- Boston: Martinus Nijhoff Publishers, 2008) 17

MitChel, ANDRew D. The Legal Principles in the WTO (New York: Cambridge University Press, 2008)

Reinhart, Carmen \& Rogoff, Kenneth. This Time is Different: Eight Centuries of Financial Folly (Princeton New Jersey: Princeton University Press, 2009)

SCOTT, Hal S \& GelPeRN, Anna. International Finance Law and Regulation (London: Sweet \& Maxwell, 2012)

Van den Bossche, Peter. The Law and Policy of the World Trade Organization: Text, Cases and Materials (New York: Cambridge University Press, 2005)

Zacharias, Diana. "Article I gats: Scope and Definition" in Ruideger Wolfrum, Peter-Tobais Stoll, \& Clemens Feinaugle, eds., Max Planck Commentaries on World Trade Law: WTO Trade in Services (Leiden- Boston: Martinus Nijhoff Publishers, 2008) 31

\section{Articles}

Adams, Kenneth A. "Drafting Matters" NY Lw Jrnl. Backpage (5 July 5 2002) <http://www.adamsdrafting.com/downloads/Drafting-Matters.pdf>

Allen, Franklin \& Herring, Richard. "Banking Regulation versus Securities Market Regulation" (2001) Wharton School University of Pennsylvania (Working Paper 01-29) <http://finance. wharton.upenn.edu/ allenf/download/Vita/0129.pdf>

BAELE, LiEven et al. "Flights to Safety" (2013) National Bureau of Economic Research (Working Paper n. ${ }^{\circ}$ 19095) <http://www.nber.org/papers/w19095.pdf>

Barth James R, Caprio Gerard JR. \& Levine Ross, "Banking Regulation and Supervision: What Works Best?" (2001) The World Bank Policy Research (Working Paper n. ${ }^{\circ}$ 2725)

Borio, Claudio. "Towards a Macroprudential Framework for Financial Supervision and Regulation?" (2003) BIS Working Paper n. ${ }^{\circ} 128$

BrunNERmeier, Markus et al. "The Fundamental Principles of Financial Market Regulation" (2009) Geneva Reports on the World Economy 11 (International Centre for Monetary and Banking Studies \& Centre for Economic Policy Research)

Castro-Riberos, Miguel. "Colombia's Policy Space for Prudential Regulation: an Analysis from its International Trade Commitments" (2013) 23 Rev. Col. Der. Intern. 119

Clement, PIET. "The Term 'macro-prudential' origins and evolution" (2010) BIS Quarterly Rev. (QL) <http://www.bis.org/publ/qtrpdf/r_qt1003h.pdf>

Delimatsis, Panagiotis \& Suavé, Pierre. "Financial services trade after the crisis: Policy and legal conjectures". (2010) 13(3) J. Int'l Econ. L. 837.

Diamond Douglas \& Dybvig Phillip. "Bank Runs, Deposit Insurance, and Liquidity" (1983) 91(3) Jrnl. of Pol. Econ. 401 
Dijkman, Miguel. "A Framework for Assessing Systemic Risk" (2010) The World Bank (Policy Research Working Paper n. ${ }^{\circ}$ 5283) < http://www- wds.worldbank.org/external/default/wDSContentServer/IW3P/IB/2010/04/26/000158349_20100426151636/Rendered/PDF/WPS5282.pdf>

Glavan, Bogdan \& ANGHel, Flava. "We are Not Macroprudentialists: A Skeptical View of Prudential Regulation to Deal with Systemic Externalities" (2013) 17(3) The Independent Rev. 349 ILOLLARI, ORKIDA \& GJINO, GENTIANA. "Implementation of macro- and micro-prudential regulation" (2013) 5(1) Rev. of Applied Socio-Econ. Research

JANIS, MARK WeStON. "The Ambiguity of Equity in International Law" (1983) 9(7) Brook. J. Int'1 L. <http://ssrn.com/abstract=1101686>

KeY, Sydney J. "Trade liberalization and prudential regulation: the international framework for financial services" (1999) 75 R.I.I.A. 61

LOWE, Vaughan. "The Role of Equity in International Law" Aus Yb Int'1 L. 54

MAES, IVO. "On the origins of the BIS macro-prudential approach to financial stability" (2009) National Bank of Belgium (Working Paper n. ${ }^{\circ}$ 176)

McAllister Shepro, Mary. "Preserving National Regulatory Autonomy in Financial Services: The GATS' Prudential Carve-Out" (2013) Notre Dame University (Social Science Research Network) <http://ssrn.com/abstract=2418764>

Morris, Stephen \& Shin, Hyun. "Financial Regulation in a Systemic Context" (2008) Brookings Papers on Economic Activity 229

Persaud, Avinash. "Macro-Prudential Regulation: Fixing Fundamental Market (and Regulatory) Failures" (2009) World Bank Group Crisis Response (Note n. ${ }^{\circ}$ 6) < http://siteresources.worldbank.org/EXTFINANCIALSECTOR/Resources/282884-1303327122200/Note6.pdf>

PRITZKER, MATT. "The Channels for Financial Contagion" (2000) The World Bank, (QL) <http:// siteresources.worldbank.org/INTMACRO/Resources/Pritsker.pdf>

Reinhold, Steven. "Good Faith in International Law" (2013) Bonn Research Paper on Public International Law n. ${ }^{\circ} 2 / 2013<$ http://ssrn.com/abstract=2269746>

SCOTT, HaL S. "How to Improve Five Important Areas of Financial Regulation" in Rules for Growtb:

Promoting Innovation and Growth Through Legal Reform (Yale Law and Economics Research Paper n. $\left.{ }^{\circ} 426,2011\right) 113 .<$ http://ssrn.com/abstract=1757982>

Suavé, Pierre. "A Plurilateral Agenda for Services? Assessing the case for a Trade in Services Agreement (TISA)" (2013) NCRR Trade Regulation < http://www.wti.org/fileadmin/user_upload/ nccr-trade.ch/wp2/publications/TISA_P_Sauve.pdf>

White, Margaret. "Equity - A General Principle of Law Recognized by Civilized Nations?" 2004) 4 QUT L. Rv. 103

Yokio-Arai, Mamiko. "Gats' Prudential Carve Out in Financial Services and Its Relation with Prudential Regulation" (2008) 57 Int'l \& Comp. L.Q. 613

\section{Miscellaneous}

Australian Government Department of Foreign Affairs and Trade, Press Release "Advancing Negotiations on services" (5 July 2012) < http://www.dfat.gov.au/trade/negotiations/services/20120705advancing-negotiations-on-trade-in-services.html> 
Australian Government Department of Foreign Affairs and Trade, Trade in Services Agreement, online $<$ http://www.dfat.gov.au/trade/negotiations/services/trade-in-services-agreement.html>

Bank for International Settlements, "About the Basel Committee" online Bank for International Settlements <http://www.bis.org/bcbs/about.htm>

Bank for International Settlements, "Basel Committee membership" online Bank for International Settlements <http://www.bis.org/bcbs/membership.htm>

Basel Committee on Banking Supervision, "Core Principles for Effective Banking Supervision" (September 2012) Bank for International Settlements <http://www.bis.org/publ/bcbs230.pdf>

Basel Committee on Banking Supervision, "Strengthening the resilience of the banking sector" (2009) Consultative Document

Basel Committee on Banking Supervision \& International Association of Deposit Insurers, "Core Principles for Effective Deposit Insurance Systems" (June 2009) Bank for International Settlements \& International Association of Deposit Insurers <http://www.bis.org/publ/bcbs156.pdf > Board of the International Organization of Securities Commission, "Principles for Financial Benchmarks" (July 2013) <http://www.iosco.org/library/pubdocs/pdf/IOSCOPD415.pdf>

BIS Monetary and Economic Department "BIS Papers n. ${ }^{\circ}$ 1: Marrying the macro- and microprudential dimensions of financial stability" (2001) Bank for International Settlements <http:// www.bis.org/publ/bppdf/bispap01.pdf>

Diccionario de la lengua española DRAE (22. Ed. Rae.es) 2001

Dictionnaire Larousse en ligne (Larrouse.fr)

European Banking Federation "EBF position on the inclusion of financial services in the Transatlantic Trade and Investment Partnership negotiations" 7 June 2013, Brussels (EBF_002430) <http:// www.ebf-fbe.eu/uploads/EBF_002430\%20-\%20TTIP\%20and\%20financial\%20services.pdf>

European Commission Directorate-General for Trade (Trade Policy Committee: Services and Investment) "TTIP negotiations: Modified EU draft proposals on trade in services, investment and electronic commerce" 2 July 2013, Brussels (QL) < http://eu-secretdeals.info/upload/EUInvestment-Text-TTIP-v_July2nd-2013_v1.pdf>

European Commission Directorate-General for Trade (Trade Policy Committee) "CETA Consolidated text" 5 August 2014, Brussels (QL) < http://www.tagesschau.de/wirtschaft/ceta-dokument-101. pdf $>$

Financial Stability Board, "About the FSB" online Financial Stability Board <http://www.financialstabilityboard.org/about/overview.htm>

Financial Stability Board, "Key Standards for Sound Financial Systems" online Financial Stability Board < http://www.financialstabilityboard.org/cos/key_standards.htm>

Financial Stability Board, "Principles for an Effective Risk Appetite Framework" (November 2013) $<$ http://www.financialstabilityboard.org/publications/r_131118.pdf>

Financial Stability Board, "Recovery and Resolution Planning for Systematically Important Financial Institutions: Guidance on Identification of Critical Functions and Critical Shared Services" (16 July 2013) <http://www.financialstabilityboard.org/publications/r_130716a.pdf>

Cited as: FSB-Guidance on Id. Critical Functions \& Services

Financial Stability Board, "What are Standards" online Financial Stability Board <http://www. financialstabilityboard.org/cos/standards.htm> 
Gerlach, Stefan. "Defining and Measuring Systemic Risk" (23 November 2009) European Policy Dep. <http://www.europarl.europa.eu/document/activities/cont/200911/20091124ATT6515 4/20091124ATT65154EN.pdf>

Group of Ten, "Report on Consolidation in the Financial Sector" (2001)<http://www.bis.org/ publ/gten05.pdf>

Group of Twenty, Press Release, "Global Plan Annex: Declaration on Strengthening the Financial System" (2 April 2009) <http://www.g20.utoronto.ca/2009/2009ifi.html>

Group of Twenty, "High Level Principles on Financial Consumer Protection" (October 2011) $<$ http://www.oecd.org/daf/fin/financial-markets/48892010.pdf>

Hufbauer Gary Clyde, Jensen Bradford \& STEPHenson Sherry, '"'Framework for the International Services Agreement" (2012) Peterson Institute for International Economics < http://www.piie. com/publications/pb/pb12-10.pdf>

ICTSD, "Services Openings Eyed by some WTO Members"16(9) Bridges Weekly Trade News Digest (7 March 2012) 5. <http://www.ictsd.org/sites/default/files/review/bridgesweekly/bridgesweekly16-9.pdf>

International Association of Deposit Insurers, "About IADI" online International Association of Deposit Insurers <http://www.iadi.org/aboutIADI.aspx>

International Association of Deposit Insurers, "Members and Participants" online International Association of Deposit Insurers <http://www.iadi.org/aboutIADI.aspx?id=48>

International conference of plenipotentiaries on the law of treaties, GA Res 2166 (XXI), UNGAOR, 1484th plenary meeting, (1966)

International Law Commission, "Draft Articles on the Law of Treaties with Commentaries" (1966) II Yearbook of the International Law Commission <http://legal.un.org/ilc/texts/instruments/ english/commentaries/1_1_1966.pdf >

International Monetary Fund: Monetary and Capital Markets Department "Macroprudential Policy: An Organizing Framework" (14 March 2011)

Cited as: IMF-Organizing Framework

International Monetary Fund, Bank for International Settlements \& Financial Stability Forum, "Guidance to Assess the Systemic Importance of Financial Institutions, Markets and Instruments: Initial Considerations" (20 October 2009) Report to the G-20

Merriam-Webster Dictionary (11. Ed. Merriam-Webster.com)

Office of the United States Trade Representative, Press Release "Advancing Negotiations on Trade in Services" (5 July 2012) < http://www.ustr.gov/about-us/press-office/press-releases/2012/july/ WTO-members-announce-new-phase-in-services-talks>

SOFFIELD, HEATHER. "EU, Canada's differences over financial services holding up free trade pact: documents" (2013) The Canadian Press (29 May 2013) <http://business.financialpost.com/2013/05/29/ eu-canadas-differences-over-financial-services-holding-up-free-trade-pact-documents/>

SuAvé, Pierre. "The Plurilateral Agreement on Services" (2013) European Parliament-Directorate General for External Policies <http://www.europarl.europa.eu/document/activities/cont/201 310/20131025ATT73459/20131025ATT73459EN.pdf > 
Speech by Andrew Crockett, General Manager Bank for International Settlements, Chairman Financial Stability Forum "Marrying the micro- and macro-prudential dimensions of financial stability" (21 September 2000) <http://www.bis.org/review/rr000921b.pdf>

Tucker, Todd \& Wallach, Lori. "No Meaningful Safeguards for Prudential Measures in the World Trade Organization's Financial Service Deregulation Agreements" (2009) Public Citizen $<$ http://www.citizen.org/documents/PrudentialMeasuresReportFINAL.pdf>

Trade in Services Agreement country negotiators, "Trade in Services Agreement (TISA) Annex [X]: Financial Services, Consolidation of text proposals" (14 April 2014) (Released by Wikileaks on June 192014$)<$ https://wikileaks.org/tisa-financial/WikiLeaks-secret-tisa-financial-annex.pdf> WTO Secretariat, "GATS Fact and Fiction" (2001) (QL) <http://www.wto.org/english/tratop_e/serv_e/ gats_factfiction_e.htm> 